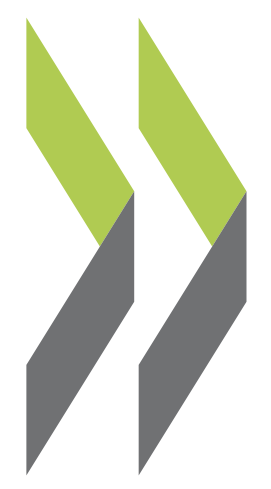

OECD Economics Department Working Papers No. 1592

What makes a productive Russian firm? A comparative analysis using Lenka Wildnerova, firm-level data 
Unclassified

English - Or. English

7 January 2020

ECONOMICS DEPARTMENT

Cancels \& replaces the same document of 19 December 2019

WHAT MAKES A PRODUCTIVE RUSSIAN FIRM? A COMPARATIVE ANALYSIS USING FIRM-LEVEL DATA

\section{ECONOMIC DEPARTMENT WORKING PAPERS No. 1592}

By Lenka Wildnerova and Hansjörg Blöchliger

OECD Working Papers should not be reported as representing the official views of the OECD or of its member countries. The opinions expressed and arguments employed are those of the author(s).

Authorised for publication by Álvaro Pereira, Director, Country Studies Branch, Economics Department.

Document available in pdf format only.

All Economics Department Working Papers are available at www.oecd.org/eco/workingpapers.

JT03456394 
OECD Working Papers should not be reported as representing the official views of the OECD or of its member countries. The opinions expressed and arguments employed are those of the author(s).

Working Papers describe preliminary results or research in progress by the author(s) and are published to stimulate discussion on a broad range of issues on which the OECD works.

Comments on Working Papers are welcomed, and may be sent to the Economics Department, OECD, 2 rue André-Pascal, 75775 Paris Cedex 16, France, or by e-mail to econ.contact@oecd.org.

All Economics Department Working Papers are available at www.oecd.org/eco/workingpapers.

On 25 May 2018, the OECD Council invited Colombia to become a Member. At the time of preparation the deposit of Colombia's instrument of accession to the OECD Convention was pending and therefore Colombia does not appear in the list of OECD Members and is not included in the OECD zone aggregates.

This document and any map included herein are without prejudice to the status of or sovereignty over any territory, to the delimitation of international frontiers and boundaries and to the name of any territory, city or area.

The statistical data for Israel are supplied by and under the responsibility of the relevant Israeli authorities. The use of such data by the OECD is without prejudice to the status of the Golan Heights, East Jerusalem and Israeli settlements in the West Bank under the terms of international law.

\section{(C) OECD (2019)}

You can copy, download or print OECD content for your own use, and you can include excerpts from OECD publications, databases and multimedia products in your own documents, presentations, blogs, websites and teaching materials, provided that suitable acknowledgment of OECD as source and copyright owner is given. All requests for commercial use and translation rights should be submitted to rights@oecd.org 


\section{ABSTRACT/RÉSUMÉ \\ WHAT MAKES A PRODUCTIVE RUSSIAN FIRM? A COMPARATIVE ANALYSIS USING FIRM-LEVEL DATA}

Productivity in Russia has fallen steadily over the past 15 years. This paper explores microlevel data to understand the contribution of individual firms to aggregate productivity. Overall, firm-level data corroborate the decline in aggregate productivity and a widening productivity gap against several European countries. They also show that the gap between "the best" and "the rest" has widened in Russia, similar to other countries. Russian markets are quite concentrated, i.e. dominated by few large firms. Larger firms tend to be more productive, but firms at the productivity frontier have become smaller and younger over time, suggesting that more support for young and innovative firms could help raise productivity. Foreign ownership is associated with higher productivity, and there is evidence that foreign firms generate positive productivity spillovers for domestic firms. Service firms belong to the most productive, yet the service sector remains underdeveloped. Mining is also very productive but less than in other countries. Differences in productivity across regions are large, even controlling for many other determinants, suggesting a lack of capital and labour mobility and knowledge transfer across regional borders.

JEL classification codes: D24, L16, O43

Keywords: Russian economy; firm-level productivity; industrial organisation; productivity gap; privatisation; foreign ownership; regional productivity differences; entry and exit of firms

\section{Quels sont les caractéristiques d'une entreprise russe productive ? Une analyse comparative des données au niveau de l'entreprise}

En Russie la productivité a fortement diminué au cours des 15 dernières années. Cet article explore des données au niveau des entreprises pour comprendre leur contribution à la productivité globale. Dans l'ensemble, ces données corroborent la baisse de la productivité globale et un écart croissant par rapport à plusieurs pays européens. Ils montrent également que l'écart entre « les meilleurs » et « les autres » a augmenté en Russie. Les marchés russes sont assez concentrés, c'est-à-dire dominés par quelques grandes entreprises. Ces dernières ont tendance à être plus productives, mais les entreprises à la frontière de la productivité sont devenues plus petites et plus jeunes au fil du temps, ce qui suggère qu'un soutien aux jeunes entreprises innovantes pourrait contribuer à accroître la productivité. Les entreprises étrangères ont souvent une productivité plus élevée, et génèrent des retombées de productivité positives pour les entreprises russes. Le secteur des services est très productif, mais reste sous-développé. L'exploitation minière est également très productive mais moins que dans d'autres pays. Les écarts de productivité entre régions sont importants, même en contrôlant pour les autres déterminants, suggérant un manque de mobilité du capital, de la main-d'œuvre et des connaissances entre régions.

Codes de classification JEL: D24, L16, O43

Mots-clés: économie russe; productivité au niveau de l'entreprise; organisation industrielle; écart de productivité; privatisation; propriété étrangère; différences régionales de productivité; entrée et sortie d'entreprises 


\section{Table of contents}

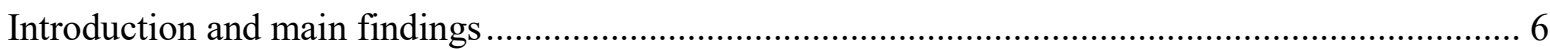

1. Productivity of the Russian economy is declining ...................................................................................... 8

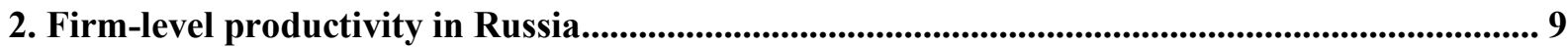

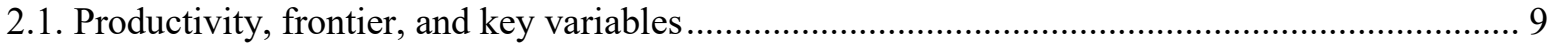

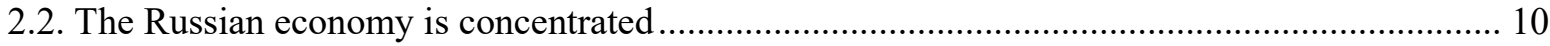

2.3. Productivity declined and remains behind other countries ..................................................... 12

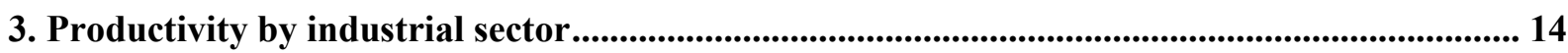

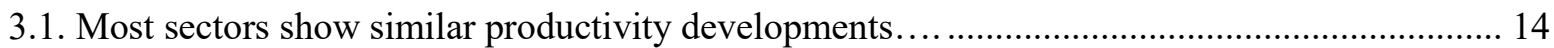

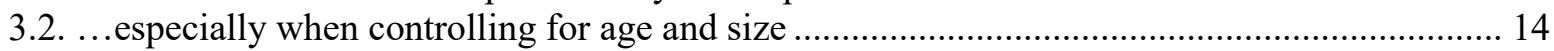

4. Productivity and firm size....................................................................................................................... 16

4.1. Larger firms are generally more productive, with exceptions ................................................. 16

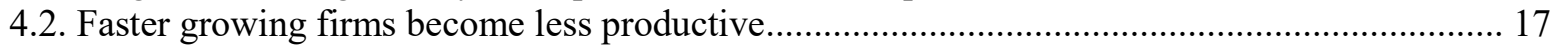

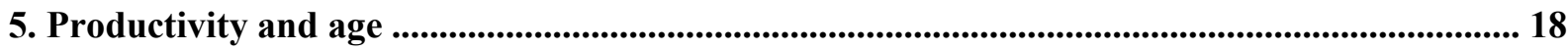

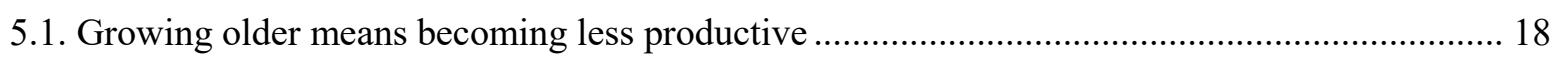

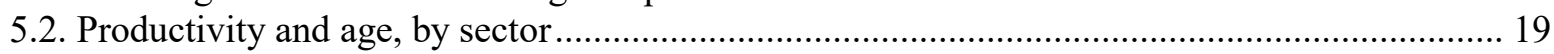

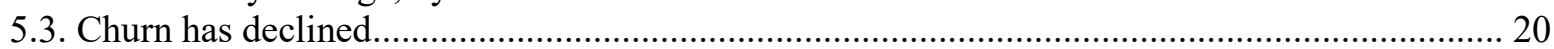

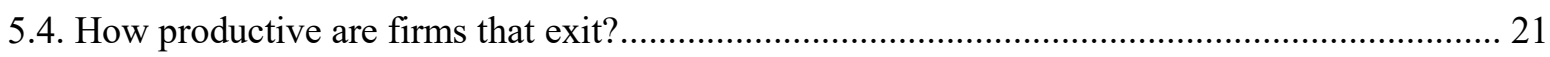

6. The productivity frontier ......................................................................................................................... 23

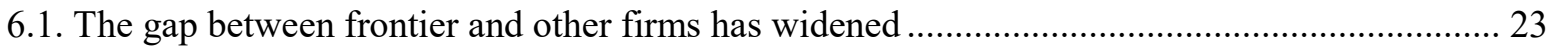

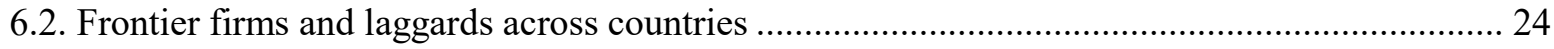

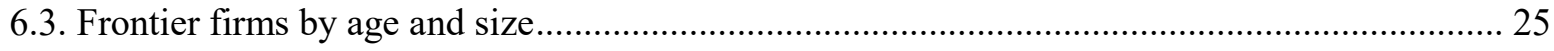

7. Foreign ownership .......................................................................................................................................... 27

8. What makes a productive Russian firm? A multivariate regression .......................................... 30

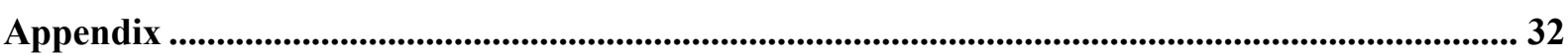

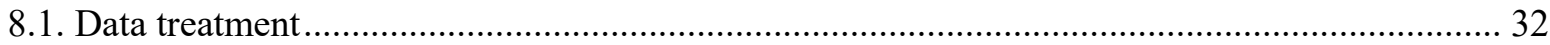

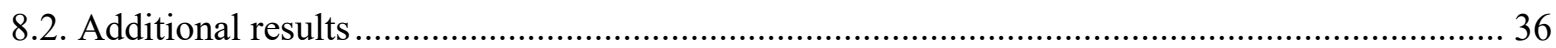

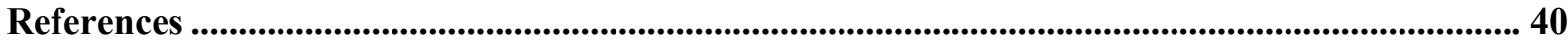

\section{Tables}

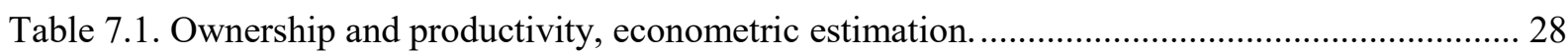

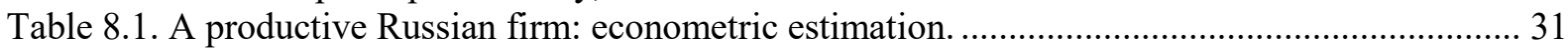

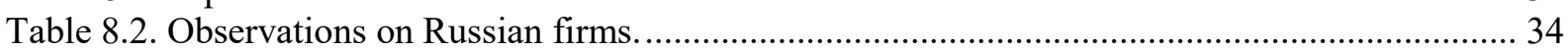

Table 8.3. Observations on micro and medium-sized Russian firms. ................................................... 35 


\section{Figures}

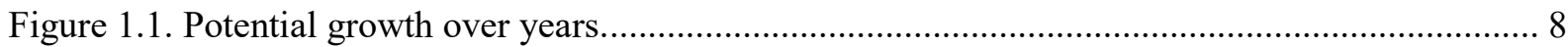

Figure 2.1. Distribution of Labour and Gross output across firms, by year...................................... 11

Figure 2.2. Employment and number of firms by firm size and country, 2010 ................................. 11

Figure 2.3. Redistribution of firms, employment, and gross output.................................................. 12

Figure 2.4. Productivity evolution in selected countries, averages, 2003-2014 ................................ 13

Figure 3.1. Productivity of firms by sector, 2003-2014 …................................................................. 14

Figure 3.2. Productivity of firms by sector, controlling for size and age ............................................ 15

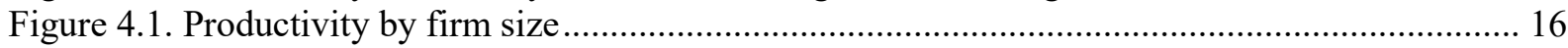

Figure 4.2. Productivity levels by employment growth, 2003-2014 .............................................. 17

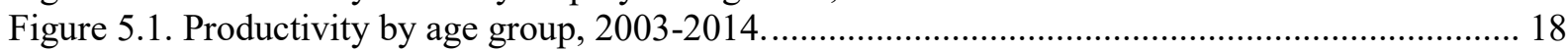

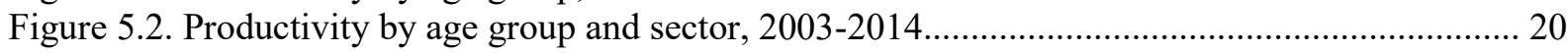

Figure 5.3. Productivity growth by age group, 2003-2007 and 2007-2013 ...................................... 20

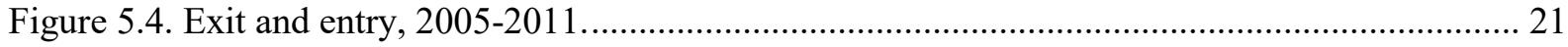

Figure 5.5. Productivity of firms that exit, enter and remain in the sample, 2005-2012 .................... 21

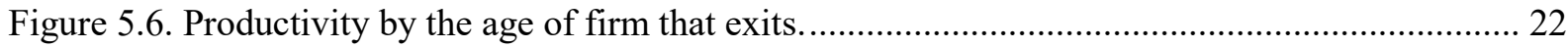

Figure 6.1. The gap between frontier firms and laggards has widened in Russia ................................ 23

Figure 6.2. Productivity frontier firms and laggards, 2003-2014 .................................................... 24

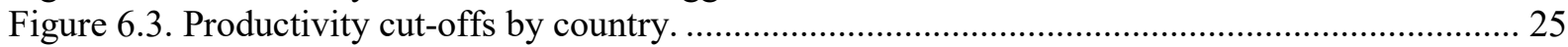

Figure 6.4. Age and size characteristics of frontier firms and laggards, 2003-2013 .......................... 26

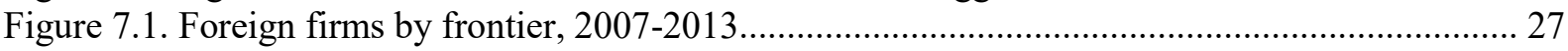

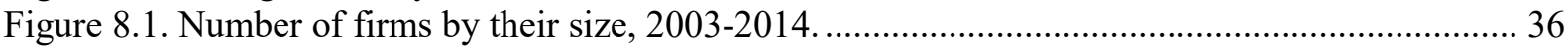

Figure 8.2. Redistribution of firms, employment, and gross output by type of firm or its location, average

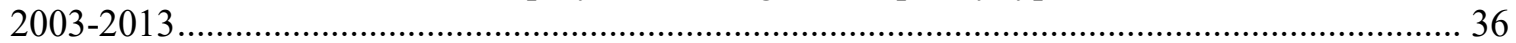

Figure 8.3. Productivity evolution in selected countries. ................................................................. 37

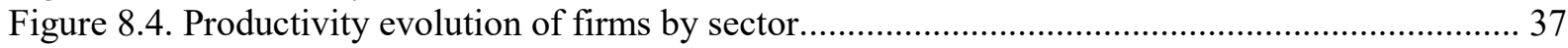

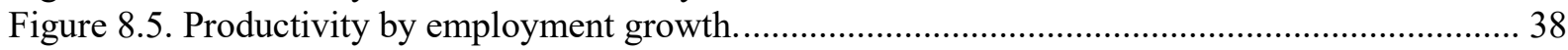

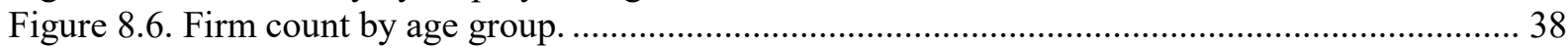

Figure 8.7. Productivity cut-offs for frontier and laggard firms......................................................... 39 


\title{
What makes a productive Russian firm? A comparative firm-level analysis
}

\author{
By Lenka Wildnerova and Hansjörg Blöchliger ${ }^{1}$
}

\section{Introduction and main findings}

1. The Russian economy has considerably slowed over the past 15 years. A rapid decline in productivity growth from $6 \%$ in the first years of the 2000 s to negative growth from 2012 on appears as the main culprit for slowing economic performance. Moreover and as in most countries, the recovery normally witnessed in post-crisis economies was, at best, short-lived. However, little is known about the drivers of productivity and the productivity slowdown at the level of individual firms in Russia. In addition, while the gap between "frontier firms" and others has widened in most OECD countries, this widening has not been documented for Russian firms so far.

2. This paper provides a descriptive analysis of productivity developments at the firm level in Russia and is organised as follows: the second section provides an overview on the decline of growth and productivity in Russia's economy. The third section assesses the productivity of Russian firms compared with firms in other major economies in Europe. Sections four, five and six discuss age, size and industrial sector as determinants of firmlevel productivity. Section seven analyses the widening gap between Russian "frontier firms" and others. Section eight examines whether foreign ownership has a positive impact on productivity. Section nine finally presents the results of a multivariate regression on the determinants of firm-level productivity in Russia.

3. The findings can be summarised as follows:

- $\quad$ The productivity decline at the macroeconomic level is corroborated by firm level data.

- As in other countries, the gap between the most and least productive firms widened in Russia, suggesting fewer resource and knowledge transfer from more to less productive firms and insufficient innovation, or growing differences in firm's ability to invest.

- $\quad$ Russia's most productive firms have become smaller and younger, unlike in many other OECD countries. Productivity tends to decline with age, except in the very first years of a firm's existence. Older firms have a higher productivity growth in sectors with high start-up costs, such as manufacturing and mining.

- $\quad$ Foreign ownership is associated with higher productivity. There is evidence of positive same-sector spillovers from foreign to domestic firms located in the same area. Privatising a state-owned enterprise seems not to foster productivity, however.

1 The authors were members of the Economics Department of the OECD at the time of writing the paper. They would like to thank Peter Gal, Abel Schumann, Piritta Sorsa, the participants of a Ministry of Economic Development workshop held in Moscow on October 19, 2018 and a Central Bank seminar held in Tula on October 13, 2019 for helpful comments and suggestions, as well as Assa Fofana for excellent editorial assistance. 
- $\quad$ Controlling for firm size and age, productivity and productivity developments in the different economic sectors are quite similar, with the exception of agriculture, which is relatively unproductive.

- $\quad$ Differences in productivity across regions are large, even controlling for all other determinants, suggesting a lack of capital and labour mobility as well as insufficient knowledge transfer across regional borders. 
1. Productivity of the Russian economy is declining

4. The growth of potential output of the Russian economy has fallen dramatically from about $7.5 \%$ annually in 2000 to less than $0.5 \%$ in 2018 (Figure 1.1). A decomposition of potential growth into the contributions from investment, employment, participation, total factor productivity and active population reveals that the main culprit for declining growth is rapidly declining productivity. At the beginning of the period, productivity growth contributed to output growth by almost $6 \%$, while in 2011 , productivity contributes by less than $0.2 \%$, and the contribution turns even negative in the following years. The Russian economy develops largely on the basis of growing employment and capital spending, while productivity is actually a drag on growth.

Figure 1.1. Potential growth over years.

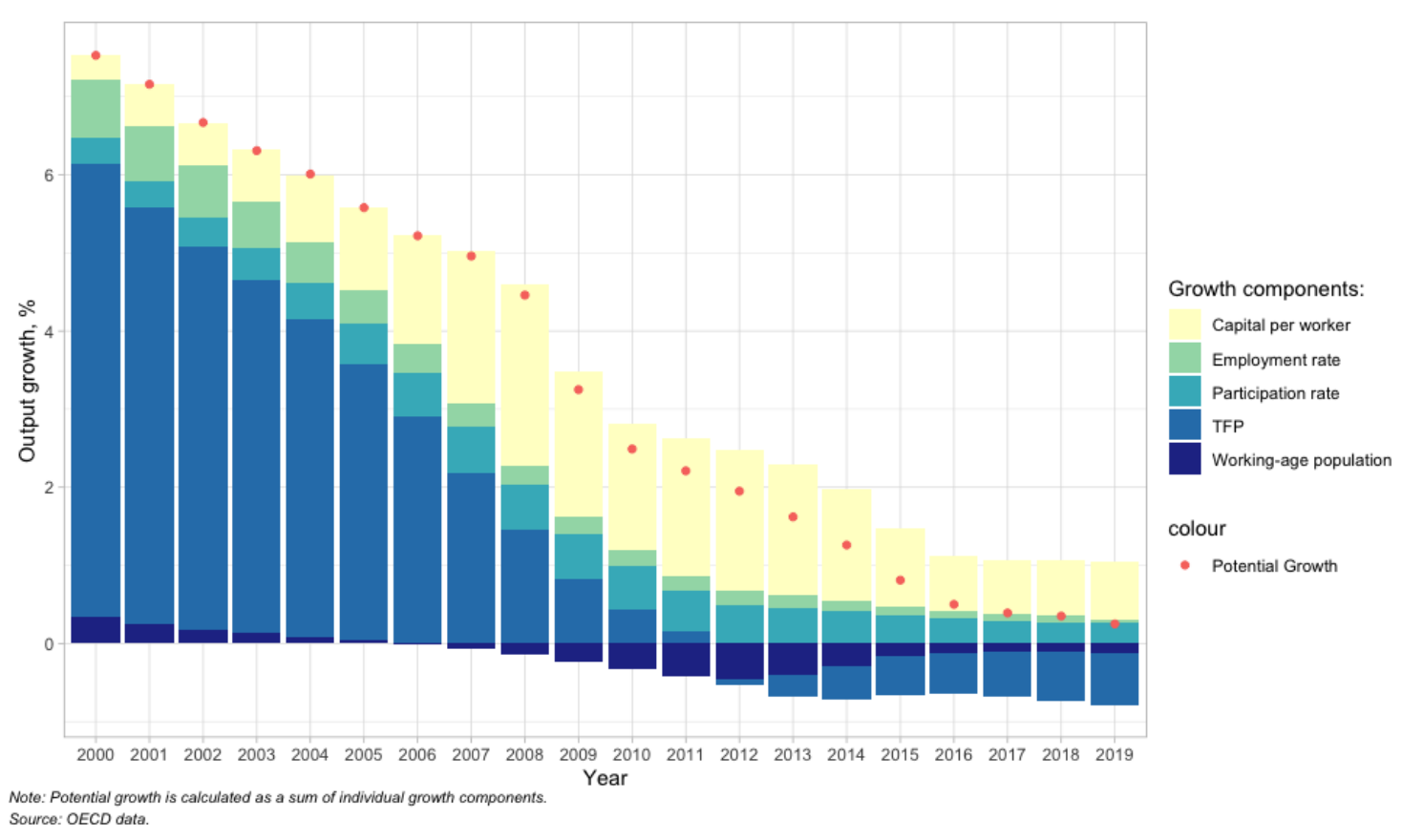

5. The aim of this paper is to mirror the macroeconomic productivity slowdown at the micro or firm level and to understand the factors that predict a Russian firm's success in terms of productivity. This can help policy makers to understand, in a more granular way, where productivity growth comes from and whether productivity dynamics at the firm level have changed over years. The focus of the paper is on a firm's age, size, sector, ownership and location and how these factors affect productivity. The findings may serve as a background for future policy evaluation and subsequent policy recommendation studies. 


\section{Firm-level productivity in Russia}

6. The paper relies on the yearly firm balance sheets provided by the OECD-Orbis database that collects the data from multiple sources for numerous countries. Data for Russia are reported for the years 2003 to 2014. The dataset consists of around 5.8 million observations, making Russia the largest country in the OECD-Orbis database. To ensure representativeness, the OECD-Orbis coverage is compared with the number of firms reported by the Russian statistical agency Rosstat. Detailed information on sources, coverage within individual data sources as well as cleaning of the dataset are described in Appendix 8.1.4.

7. Financial information such as profits or value added, needed to compute total factor productivity, is lacking for most Russian firms. For that reason, the paper relies on labour productivity or gross output per employee. One drawback of using labour productivity is that it is unable to distinguish between productivity growth resulting from capital investment or from technological improvements. As such labour productivity and total factor productivity differ, in particular for labour-intensive industries. Against this background, labour productivity is still a robust measure to understand advancements and growth differences between firms and aggregate productivity developments.

\subsection{Productivity, frontier, and key variables}

8. The productivity measure referred to throughout the paper is a log value of share of gross output per worker for each firm, $\ln i t=\ln \left(G O_{i t} / L_{i t}\right)$, where $i$ refers to firm and $t$ is the time dimension. The frontier is defined as the top 5\% of firms within their sector in a given year based on their average productivity over their presence in the sample. The average productivity is calculated as $l p_{i}=\Sigma_{t=1}^{T} l p_{i t} / \Sigma f_{t}$ where $T$ is the last year the firm $i$ is present in the data and $f_{t}$ takes value 1 if the firm is in the data in the year $t$. As such, one-time productivity drop will not make a firm change its frontier position. The only way a group of frontier firms changes is through an entry of new highly productive firms into the sample or an exit of the existing frontier firms. ${ }^{2}$

9. Firm size is given by its number of employees in a given year. The OECD definition of size of the firm uses cut-off levels at 10, 20, 50, 250 employees, corresponding to micro, small, small-medium, medium and large firm respectively. This definition of size is used throughout the paper, unless specified otherwise. To allow for comparison with Russian national statistics (Rosstat) in Table 8.2 and Table 8.3, the definition is modified to match the national definition to cut-off levels at firm size of 15, 100, and 250 employees to match the Rosstat definition of micro, small, medium and large firms.

10. The age of a firm is defined as the difference of the current year and the year of incorporation. Firms are considered as starting firms if their age is 0 or 1 year at time $t$, young firms (2-5 years), stable firms (6-10 years) and finally, old firms which are 10 years old or older. In addition to age, tdate of incorporation defines the entry of the firm into the

\footnotetext{
2 This deviates from the definition in Andrews, Criscuolo, and Gal (2016), who use the 100 best firms, top $5 \%$ of the productivity distribution, or, alternatively, 2 and $10 \%$ of distribution of the actual productivity in time $t$ or based on the 3-year moving average. The definition used in this paper permits to understand the productivity evolution of a pool of the same firms, or, in case of a new firm entry, the general direction of the best firms.
} 
market. Firm exit from the market is defined as exit from the OECD-Orbis database, but these two exits need not coincide and hence exit rates must be interpreted with caution.

11. OECD-Orbis also provides an industry sector classification for each firm. This paper refers to divisions of the Nace code (the second level in the Nace classification hierarchy). Alternatively, service sectors sections are clustered to compare all service industries (Nace2 Rev.2 numerical codes 35.00 and above) with Manufacturing (codes 1033), Mining and quarrying (codes 05-09) and Agriculture, forestry and fishing (codes 0103 ). Finally, this study defines foreign firm as a firm with $50 \%$ ownership by an entity from a foreign country. In total, the number of evaluated firms ranges from260 000 in 2003 to 870000 in 2014. Descriptive statistics are shown in the Appendix.

\subsection{The Russian economy is concentrated}

12. Russian markets are concentrated, with a small number of large firms accounting for the majority of activity (Figure 2.1). This partly reflects the legacy of socialist times, although market concentration also rose in other European countries, likely affecting innovation and income inequality (Bajgar et al., 2019 $\left.9_{[1]}\right)$. Ten percent of firms employ twothirds of the workforce and produce almost $90 \%$ of the output. Moreover, market concentration has increased since 2003, with the largest firms accounting for an everincreasing share of output. As such, the Russian economy is more concentrated than a selection of European countries, overtaken only by France (Figure 2.2). Moreover, Russia has the smallest share of micro-sized firms of all countries under scrutiny, suggesting that new firms in Russia encounter particular difficulties to enter the market. 
Figure 2.1. Distribution of Labour and Gross output across firms, by year.
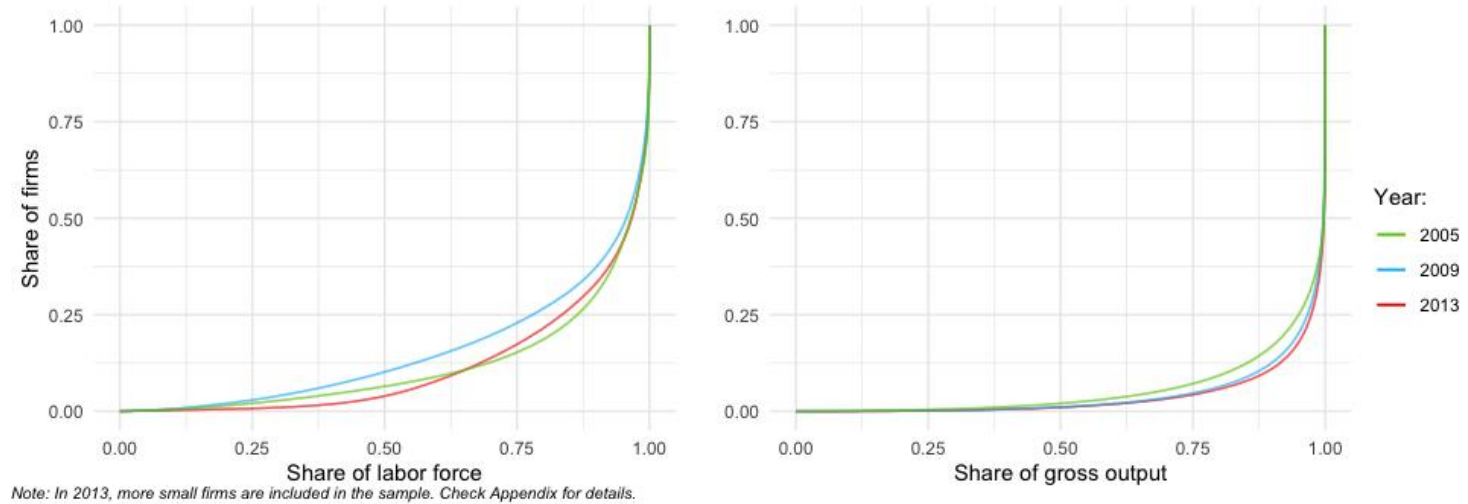
Note: In 2013, more small firms are included in the samplo:

Figure 2.2. Employment and number of firms by firm size and country, 2010.

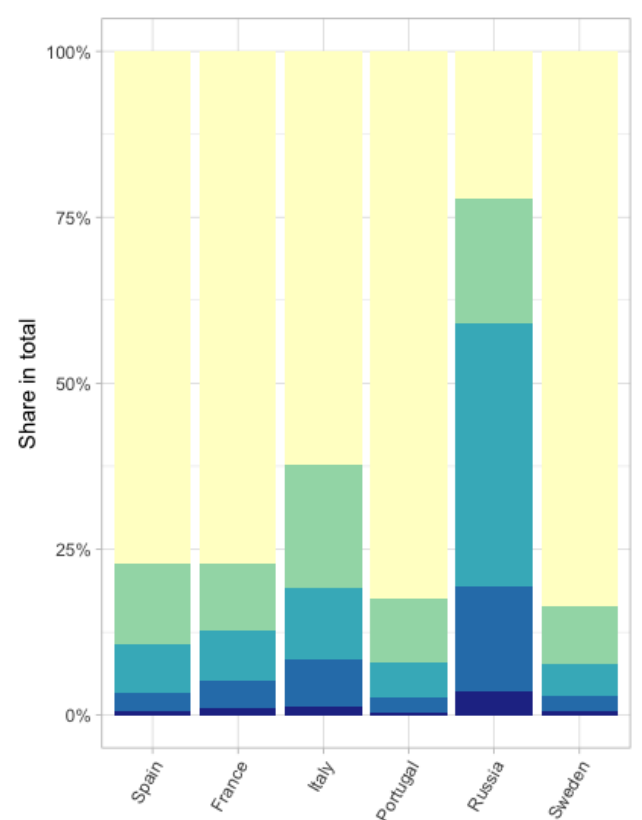

(A.) Share of firms.

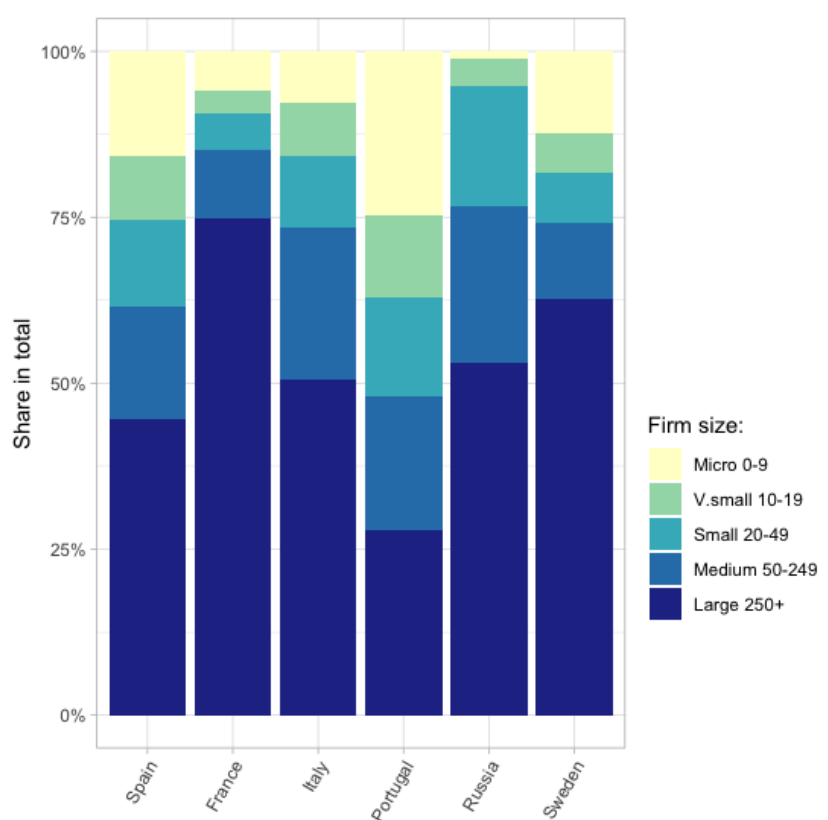

(B.) Share of employment.

Notes:

1. Selection of most-represented countries in $O E C D$-Orbis database.

2. The construction of database is such that it tends to represent larger firms wet

4. The following is the number of firms this graphic is based on following number of firms: France: 250 274; Italy: 210 988; Portugal 223 498; Russia 424 754; Sweden 166 741.

5. Firm size is given by number of employees.

Sources: $O E C D$ calculations based on OECD-Orbis data.

13. Large firms are known for being more productive, paying higher wages, and disproportionally more participating in trade than small firms on average (Bernard and Jensen, 1999 [2] $)$. Yet, a large body of research points out the contributions of small firms in job creation, output, and productivity growth. In many countries, small and medium-sized enterprises are a major source of net job creation and produce an important share of value added, contribute to economic diversification and resilience of the economy (OECD, $2019_{[3]}$ ). New and small firms also tend to drive innovation. As such, the Russian economy 
might not fully exploit the potential of its entrepreneurs. Moreover, high market concentration and a lack of small and medium-sized firms could be responsible for the large wage and income inequality observed in Russia (OECD, 2017 $\left.7_{[4]}\right)$

Figure 2.3. Redistribution of firms, employment, and gross output.

By age and sector. Average, 2003-2013.

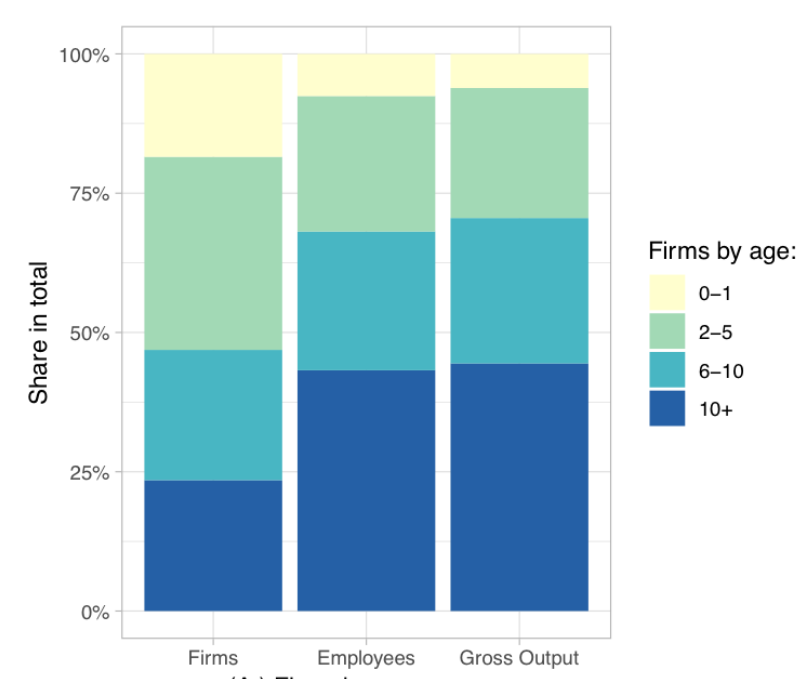

(A.) Firms by age groups.

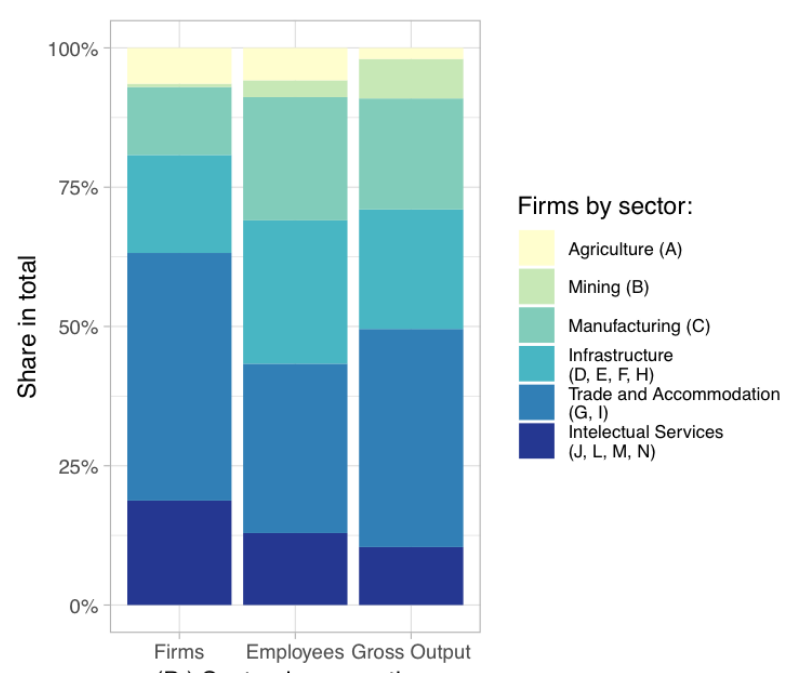

(B.) Sectoral aggregation.

Notes:

1. Averages over 2003-2013 period

2. In Figure (A), firms can change the age group if they pass the age treshold. Sources: $O E C D$ calculations based on $O E C D-O r b i s$ data.).

14. The joint Trade and Accommodation sector are the largest in the Russian economy with around $35 \%$. Only a few very large firms are active in mining and oil and gas extraction, accounting for 5\% of employment and 10\% of GDP, suggesting high productivity of this sector. The service sector is underdeveloped compared to other OECD countries but quite productive, as around $40 \%$ of the workforce produce half of total output of the Russian economy. Lastly, agriculture accounts for $2 \%$ of total output but $6 \%$ of the workforce, which implies that agriculture is the least productive sector of the Russian economy (Figure 2.3, Panel B). More than $50 \%$ of all firms are less than ten years old, reflecting the legacy of socialist times (Figure 2.3, Panel A).

\subsection{Productivity declined and remains behind other countries}

15. The productivity of Russian firms lags considerably behind other countries (Figure 2.4). ${ }^{3}$ Moreover, productivity of the average firm declined between 2003 and 2014, and more so than in most other countries, although absolute values have to be taken with some care due to the PPP conversion. The conspicuous fall in 2014 could be related to the collapse of oil prices and sanctions and countersanctions following the Ukraine crisis. Trends are similar across different productivity aggregations and weighing procedures. The

${ }^{3}$ Countries selected on the basis of comparable representativeness in OECD-Orbis data. If small, log differences can be approximated as percentage change such that a 0.05 log point difference implies a 5\% change. Financial data are deflated and converted using industry-level PPP. 
productivity of the median firm follows a similar trajectory. Finally, the average productivity of the 100 most productive firms - which tend to be also more export-oriented - in each industrial sector is also declining and remains below productivity of the 100 most productive firms in other countries, suggesting a loss of competitiveness and export opportunities, at least as compared to European counterparts (Figure 8.3 in Appendix) ${ }^{4}$.

Figure 2.4. Productivity evolution in selected countries, averages, 2003-2014.

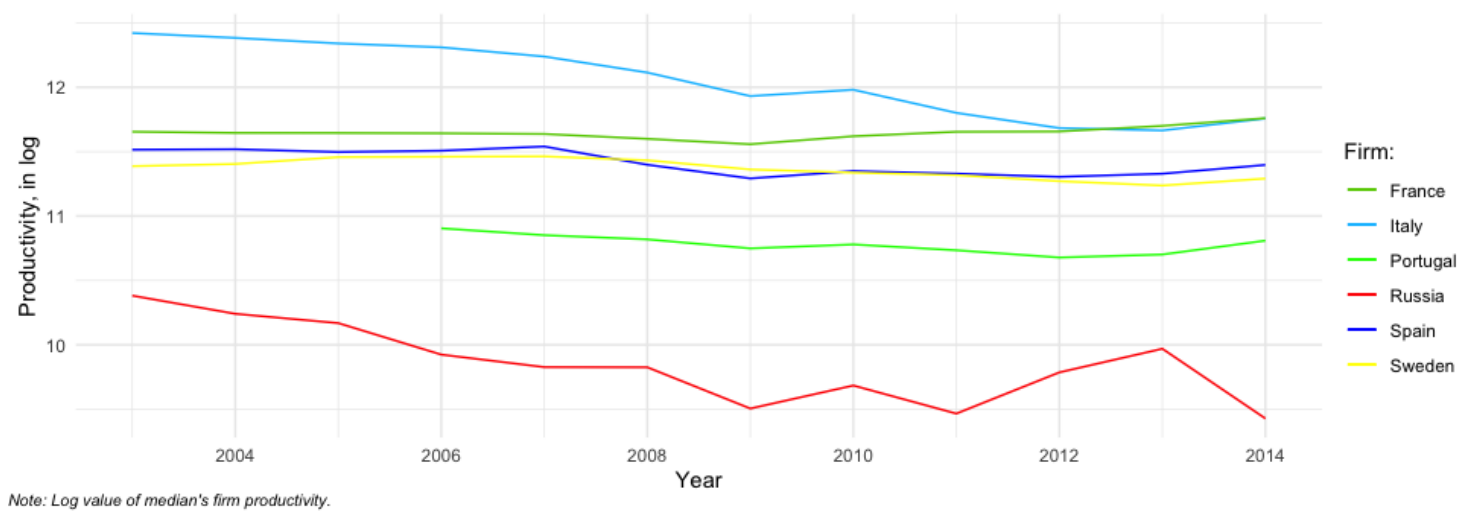

Source: OECD calculations based on OECD-Orbis data.

\footnotetext{
${ }^{4}$ An exception for those sectors represented by less than 100 firms.
} 


\section{Productivity by industrial sector}

16. This section provides an overview on productivity by industrial sector. Firms are assigned into four sectors: agriculture, mining and oil extraction, manufacturing, and services. ${ }^{5}$ These broad-defined sectors are heterogeneous in terms of different technological, human capital, and investment characteristics. Already at this level of aggregation, the four groups of firms display distinct productivity patterns.

\subsection{Most sectors show similar productivity developments...}

Figure 3.1. Productivity of firms by sector, 2003-2014

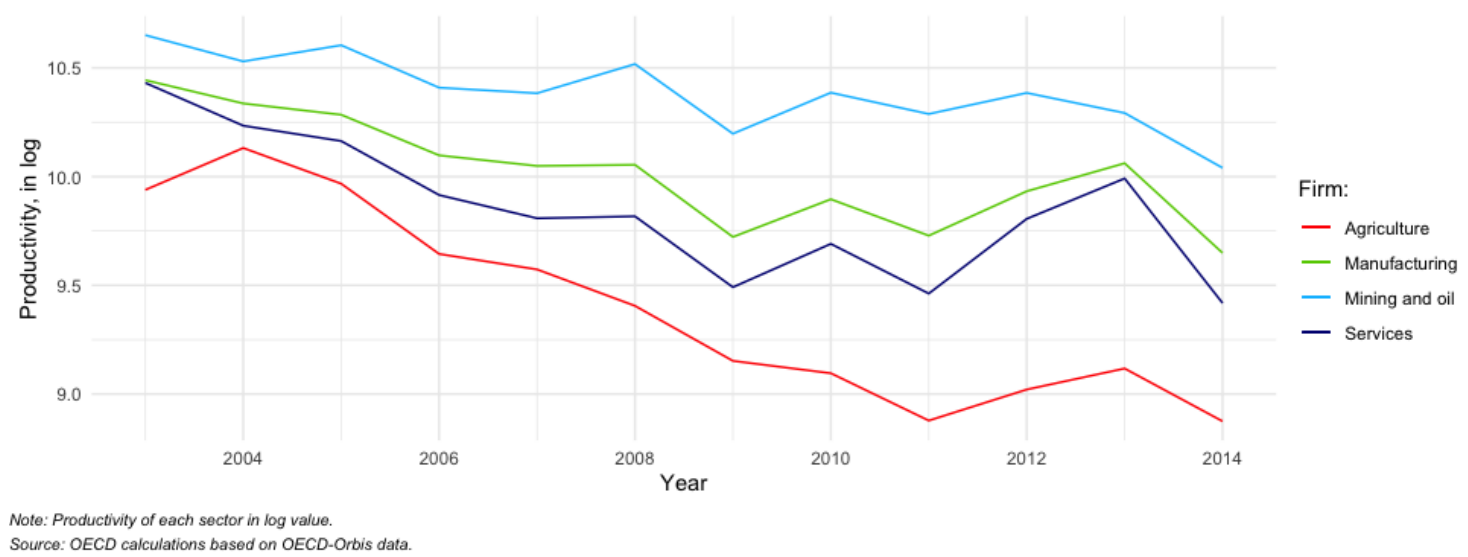

17. Productivity fell in all industrial sectors between 2003 and 2014, and differences between sectors widened (Figure 3.1). Mining firms have the highest initial productivity at the beginning of the sample, followed by manufacturing, and then by services. Productivity of an average firm in the mining sector fell by more than $0.5 \log$ points. Productivity in the agricultural sector fell even more, and the gap between the average agricultural firm and firm in other sectors widened further. If the analysis considers only large firms, the fall in productivity is less pronounced, with an exception of the services sector, where productivity of small firms fell less than those of large firms (Figure 8.4 in Appendix).

\section{2. ...especially when controlling for age and size}

18. Firms in individual sections of each industry differ in terms of size, age and productivity. It is therefore important to take individual firm differences such as firm size or age into account to be able to compare the firms of similar characteristics. Regression analysis permits to understand how size and age change the productivity within the same sector of activity. For this purpose, the following equation is estimated:

\footnotetext{
${ }^{5}$ Agricultural production includes Divisions ofNace 2 Rev.2 from Division 1to 8. Mining and oil extraction includes Divisions of Nace 2 Rev.2 from 9 to 12. Manufacturing refers to firms in Divisions of Nace 2 Rev. 2 from 13 to 32. Services refer to all firms in Nace 2 Rev.2 from 33 to 82.
} 


$$
\operatorname{lp}_{\mathrm{i}, \mathrm{t}}=\beta_{0}+\beta_{1} \text { size }_{\mathrm{i}}+\beta_{2} a g e_{\mathrm{i}, \mathrm{t}}+\gamma_{\mathrm{s}}+\varepsilon_{\mathrm{it}}
$$

19. where $i$ represents firm, $s$ stands for 2-digit sector, and $t$ for the time dimension. The dependent variable is log value labour productivity based on gross output used throughout the paper, and sector fixed effects, $\gamma_{s}$ are common 2-digit-sector-level trends across firms. Firms are classified into age and size clusters as defined in Section 2.1. The labour productivity is estimated with controls for size, age, and division of the sector for each year and each sectoral aggregation (Agriculture, Manufacturing, Mining, and Services) to ensure that these variables are not the ones driving the productivity differences within each sector aggregation.

20. If all firms in Russia were of the same size and age, they would have similar productivity levels between 2008 and 2014 in all sectors except for agriculture. Controlling for size and age, firms in service sectors were the most productive in 2003, followed by firms in manufacturing. Agriculture and mining had productivity at the same level in 2003. Over time, productivity declined in all sectors, yet agriculture stands out (Figure 3.2). Productivity in agriculture fell rapidly until 2011, with some recovery between 2011 and 2013. Overall, most of the productivity difference between sectors are driven by varying size and age of firms across sectors.

Figure 3.2. Productivity of firms by sector, controlling for size and age

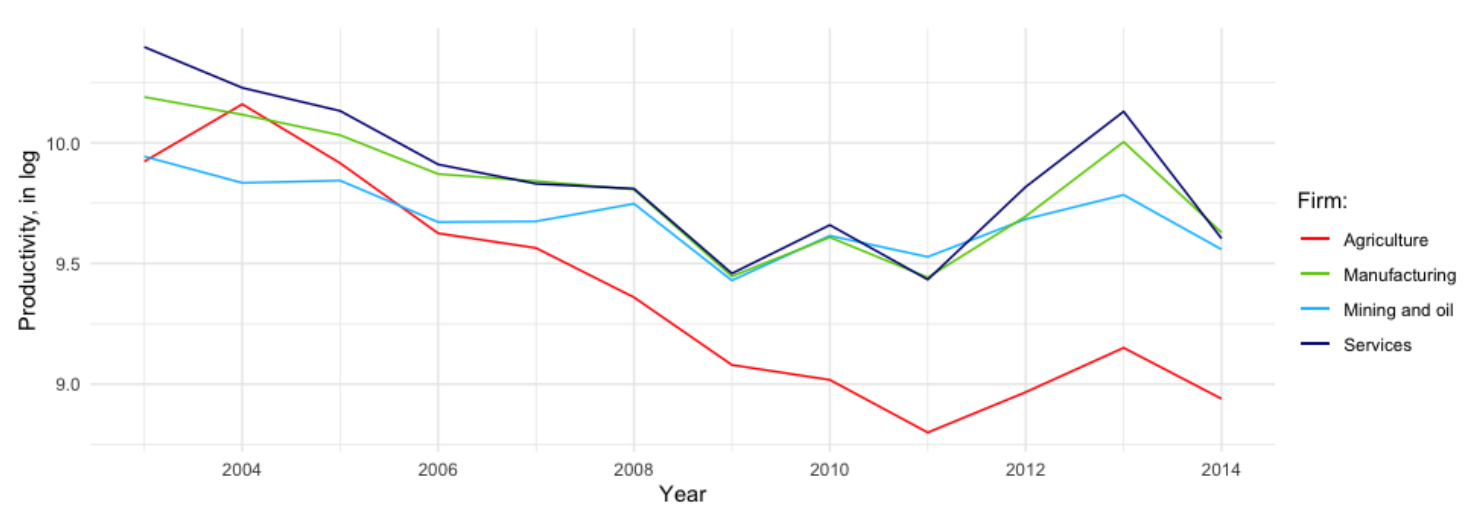




\section{Productivity and firm size}

21. Firm size plays an important role in productivity dynamics. More than $60 \%$ of the universe of Russian firms are micro enterprises and very small firms with less than 20 employees. Additional $25 \%$ of firms are small (between 20 and 49 employees). While medium and large firms account for a large part of employment (Criscuolo, Gal and Menon, $2014_{[5]}$ ), small and innovative firms are important drivers of a dynamic economy (OECD $\left(2016_{[6]}\right)$, EIB $\left.\left(2013_{[7]}\right)\right)^{6}$. Importantly, start-ups and young innovative firms contribute substantially to net job creation (Haltiwanger, Jarmin and Miranda, 2011 ${ }_{[8]}$ ). Given such a large number of small firms, policies focused on improving their productivity and supporting the innovative start-ups can have a considerable impact on growth.

\section{Figure 4.1. Productivity by firm size}

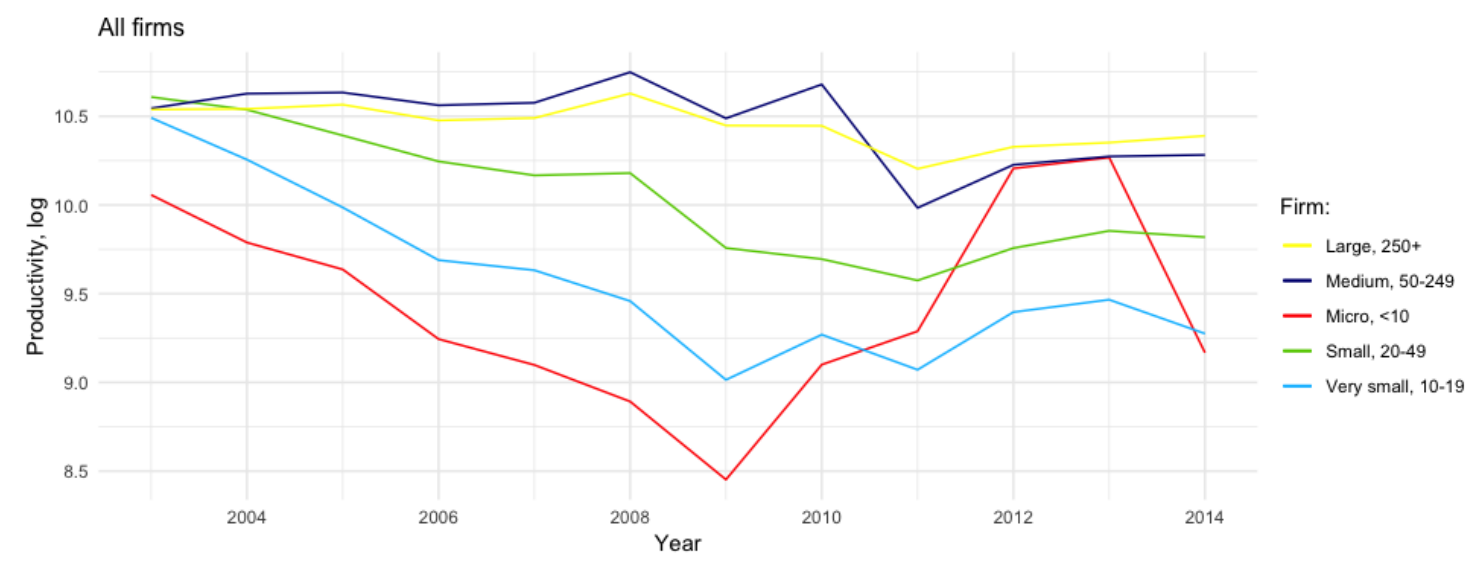

Source: $O E C D$ calculations based on $O E C D$-Orbis data.

\subsection{Larger firms are generally more productive, with exceptions}

22. Productivity is related to firm size, with larger firms being generally more productive and less affected by the productivity decline prevalent in firms of smaller size between 2003 and 2014 (Figure 4.1). The average productivity of firms with less than 50 employees tends to be lower. Micro-sized firms are volatile over time yet their productivity grew overall after 2009. Two factors could explain that. First, unlike large firms, the least productive micro and very small firms left the market, and new firms that replaced the defunct ones were more productive (see also Figure 8.1 in the annex). Second, micro firms were able to improve their productivity much faster than their larger counterparts, whether through boosting technical efficiency, innovation, or by reducing their workforce. Despite having lost ground, Russia's largest firms are still the country's most productive, and since large firms seem better able to deal with demand shocks, their productivity is less volatile.

\footnotetext{
${ }^{6}$ The shares are computed using OECD-Orbis data for 2010. The discussion on representativeness of the OECD-Orbis and comparison with national statistics is given in the appendix.
} 


\subsection{Faster growing firms become less productive}

23. Firms with faster employment growth tend to be less productive (Figure 4.2). The effect is consistent across all growth types of firms: the smaller employment growth, the higher the level of productivity. Firms with the lowest average employment growth (bottom $25 \%$ and $25-50 \%$ quantiles) have a lower productivity average than the firms in the $50-75 \%$ of employment growth distribution and the slowest-growing firms. This is true also when looking at relatively homogenous sample of large manufacturing firms (Figure 8.5 in Appendix). However, the productivity of the fastest growing firms increased after 2009, which can be attributed to the firm's ability to adjust its workforce in a flexible way when necessary, such as in time of crisis. Alternatively, this increase in productivity can also indicate that the fastest-growing firms, especially with low productivity levels, can be also the first to exit the market during a crisis.

Figure 4.2. Productivity levels by employment growth, 2003-2014.

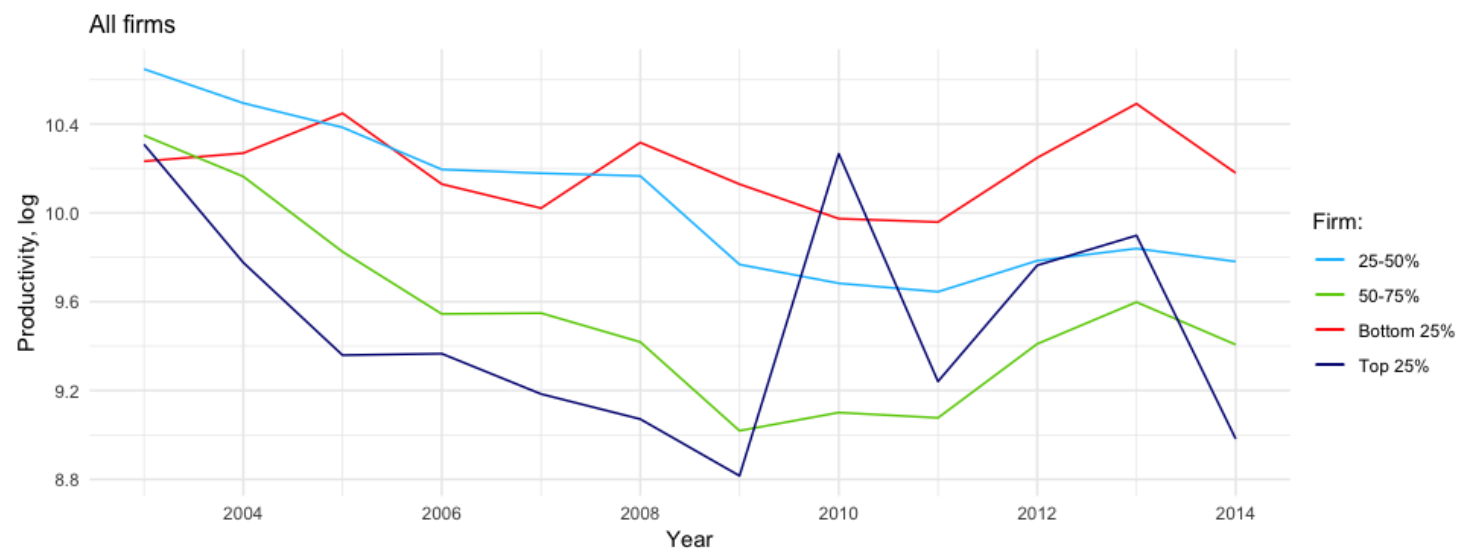


5. Productivity and age

24. New firms help introduce disruptive innovations. Firms entering the market also help create new jobs. The entry of new firms is particularly dependent on the policy environment, especially in volatile industries (Criscuolo, Gal and Menon, 2014 ${ }_{[5]}$ ). Yet, young firms are not particularly productive on average, with differences across firms being large at the beginning, as they have not sorted themselves out (Haltiwanger et al., 2017 [9] $_{\text {). }}$. As mentioned above, most Russian firms, partly due to the particularity of the political changes, are young. More than half of Russian firms are 5 years old or less, and only around $7 \%$ are more than 20 years old. With such a large share of young firms, support for firms entering the market could help boost allocative efficiency, i.e. foster both productivity and employment and help new firms to survive (Andrews and Cingano, $\left.2014_{[10]}\right)$. This section provides an analysis of productivity of Russian firms by age.

\subsection{Growing older means becoming less productive}

25. Old firms are the least productive on average as compared to firms in other age bins (Figure 5.1). Average productivity in firms 2 years old and older declined almost continuously. The youngest firms are the most volatile and in most of the years between 2003 and 2014, their average productivity was higher than productivity of any other age group, suggesting the presence of successful but unstable start-ups. Overall, the number of new entrant firms declined over the period of scrutiny (Figure 8.6 in Appendix).

Figure 5.1. Productivity by age group, 2003-2014.

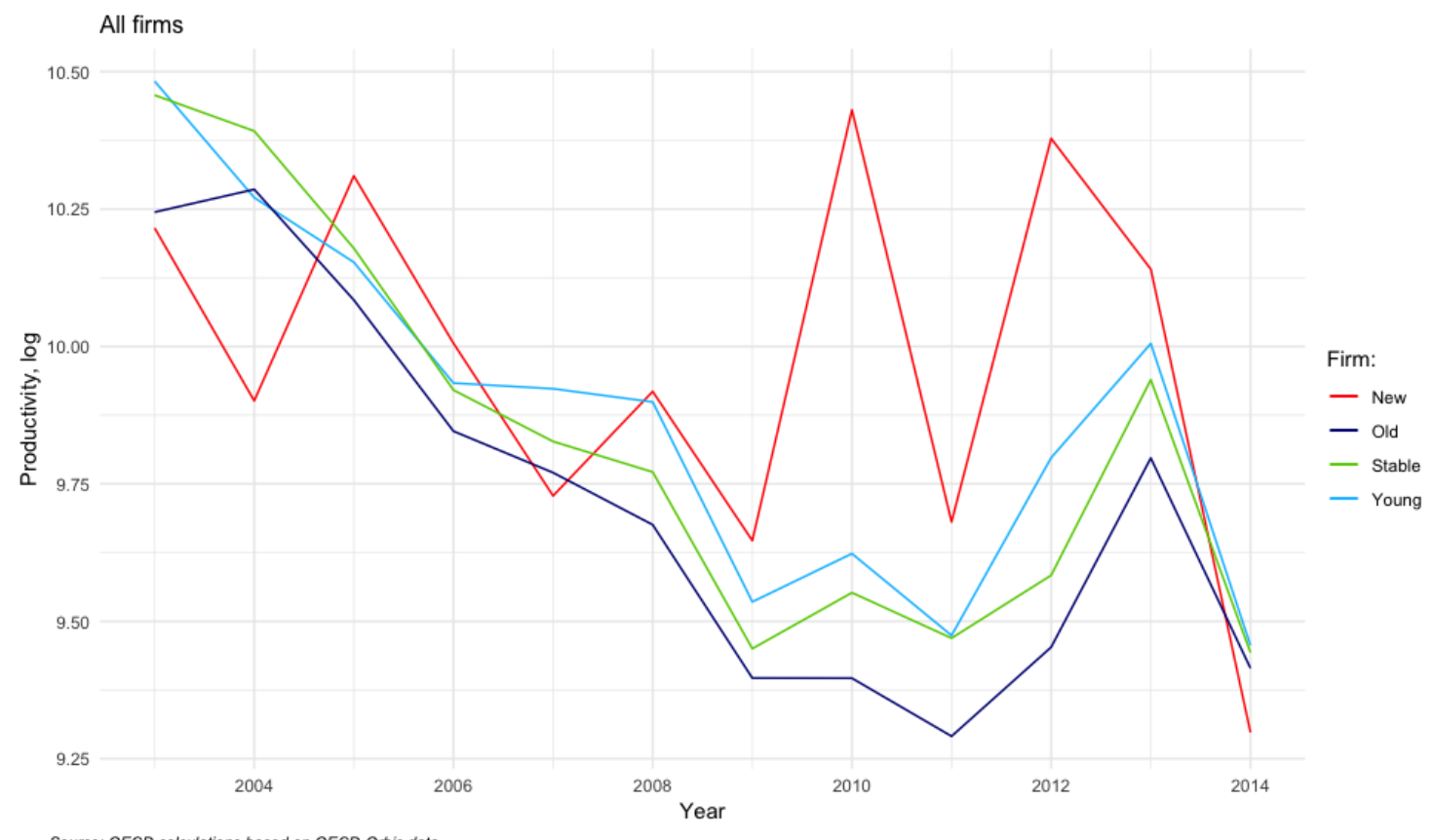




\subsection{Productivity and age, by sector}

26. Further disaggregation of age groups by sector shows a varied picture (Figure 5.2). In sectors known for high entry costs and economies of scale, such as mining and manufacturing, older firms tend to be more productive on average than younger ones. There is also a large gap between productivity of old firms and young firms in transportation and storage. In all other sectors, young firms tend to be more productive. The largest gap is between young and old firms in real estate and professional and scientific or technical activities where old firms are among the least productive firms of the Russian economy. Dividing the period further reveals that an average young firm performed well between 2003 and 2007, while older firms performed relatively better between 2007 and 2013, suggesting sluggish dynamics in the economy (Figure 5.3). 
Figure 5.2. Productivity by age group and sector, 2003-2014.

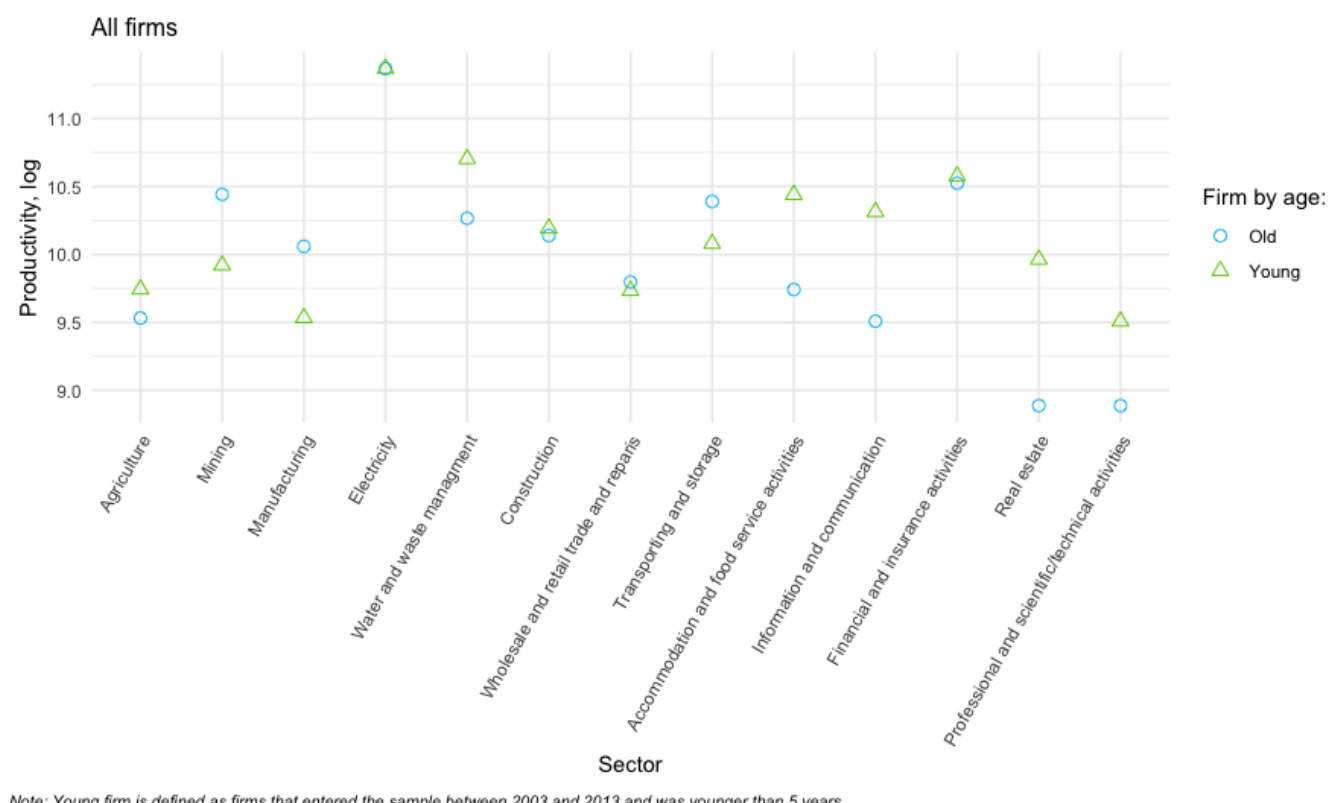

Note: Young firm is defined as firms that entered the sample between 2003 and 2013 and was younger than 5 years.

Old is defined as otherwise. This implies that firm can be up to 16 years old in 2013 and considered young.

Source: $O E C D$ calculations based on $O E C D$-Orbis data.

Figure 5.3. Productivity growth by age group, 2003-2007 and 2007-2013.

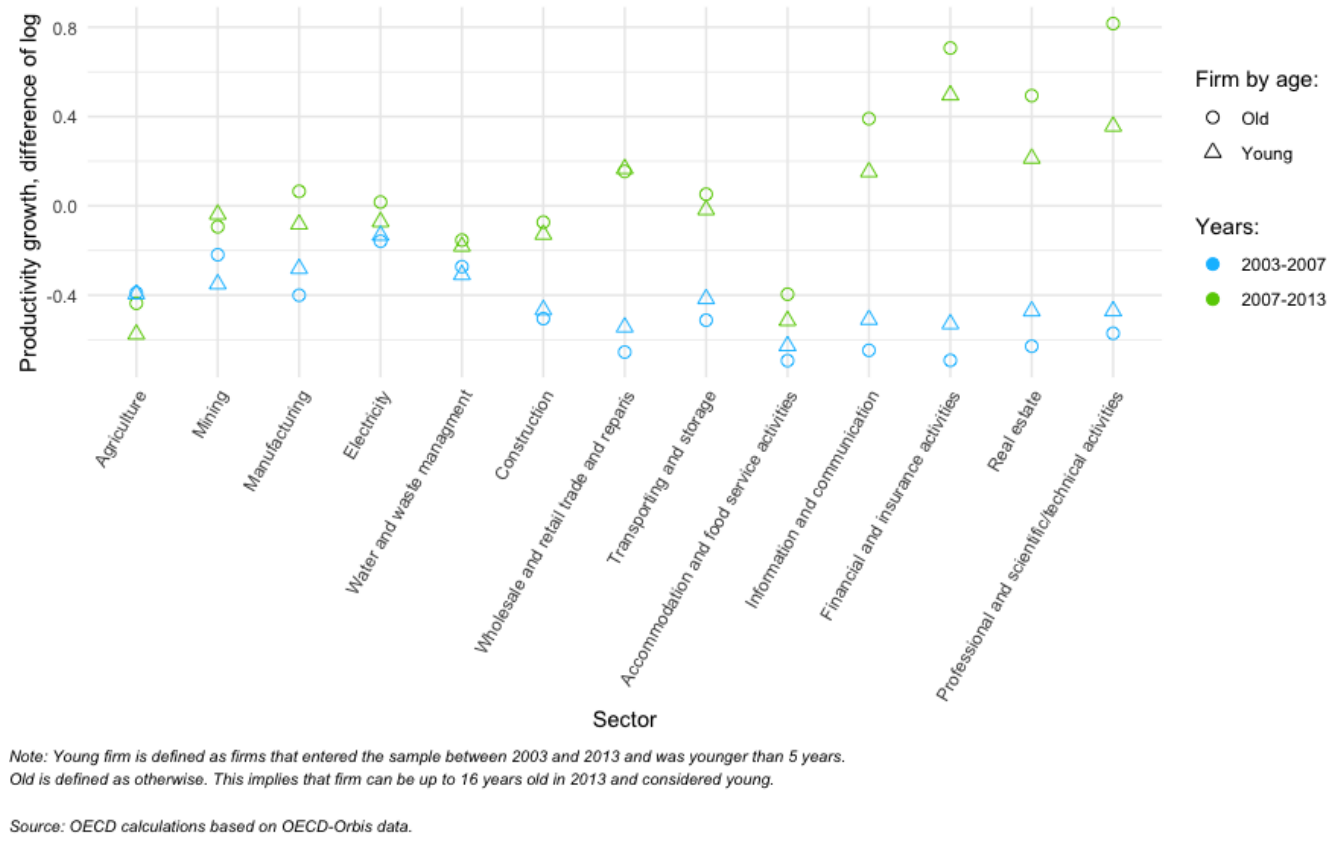

5.3. Churn has declined

27. The percentage of firms entering the market each year has declined from around $15 \%$ to $9 \%$, fluctuating over time, while the percentage of exiting firms remained more stable (Figure 5.4). More firms enter than exit the market in total, but the difference has 
become smaller over time. ${ }^{7}$ As can be expected, firms that exit are the least productive, while declining productivity over time suggests that low-productivity firms stay ever longer on the market longer, with a potential drag on aggregate productivity (Figure 5.5). New entrance firms are the most productive but their productivity is volatile.

Figure 5.4. Exit and entry, 2005-2011.

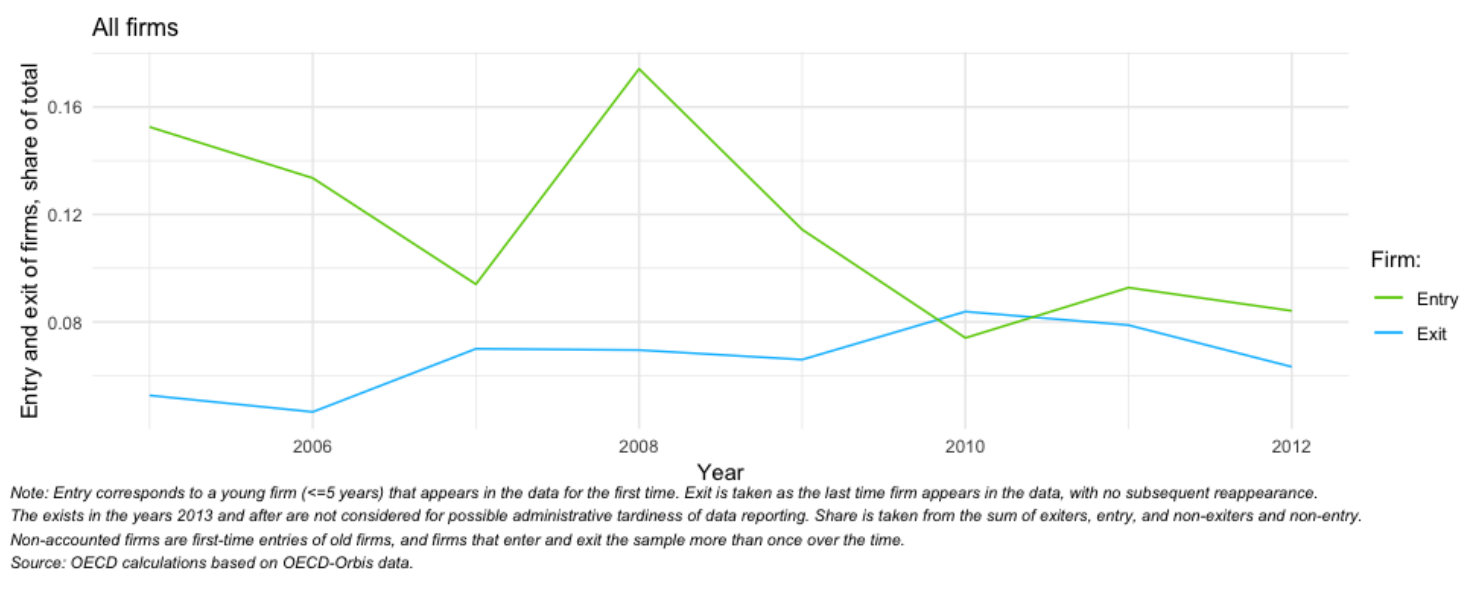

Figure 5.5. Productivity of firms that exit, enter and remain in the sample, 2005-2012.

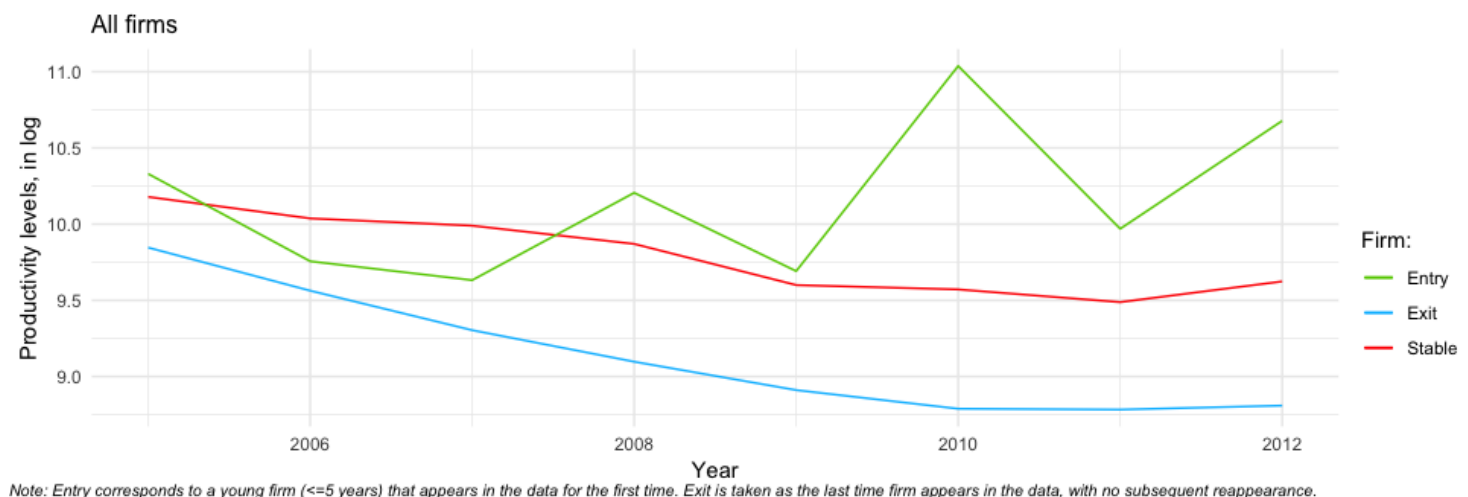

The exists in the years 2013 and after are not considered for possible administrative tardiness of data reporting. Stable firm sample excludes productivity of first-time entries of old firms, and firms that ente Results must be interpreted with caution as data might not account for all entering fims, and exit from the sample is not equivalent to exit from the market, despite large coverage suggesting that this is the Source: $O E C D$ calculations based on $O E C D$-Orbis data.

\subsection{How productive are firms that exit?}

28. It is possible to predict how long a firm will remain on the market depending on its entry productivity ${ }^{8}$. Almost universally, the higher the entry productivity, the longer the

7 The exit from OECD-Orbis does not imply market exit, but there is a high probability, with the representativeness of the data, that data sample exit and market exit coincide.

${ }^{8}$ The productivity levels are estimated as a function of age of the firm for groups of firms depending on the time they exit the data sample using a quadratic estimation. Only firms aged 20 years and less prior to 2012 are taken into account. Years 2013 and 2014 help determine whether the firm exited or remained in the OECD-Orbis data, and are excluded from the analysis once the exit status is determined. To ensure that the sector and year are not influencing the productivity curves, the productivity is first demeaned by its sector and year average. This minimizes the possibility that the 
firm will survive and stay on the market (Figure 5.6). Firms starting with the lowest productivity will most likely exit the market within 2 years of their existence. The longestsurviving firms tend to have very low productivity towards the time of their exit, suggesting that many old unproductive firms stay on the market for too long. Finally, surviving firms are the most productive, despite their falling productivity when getting older.

Figure 5.6. Productivity by the age of firm that exits.

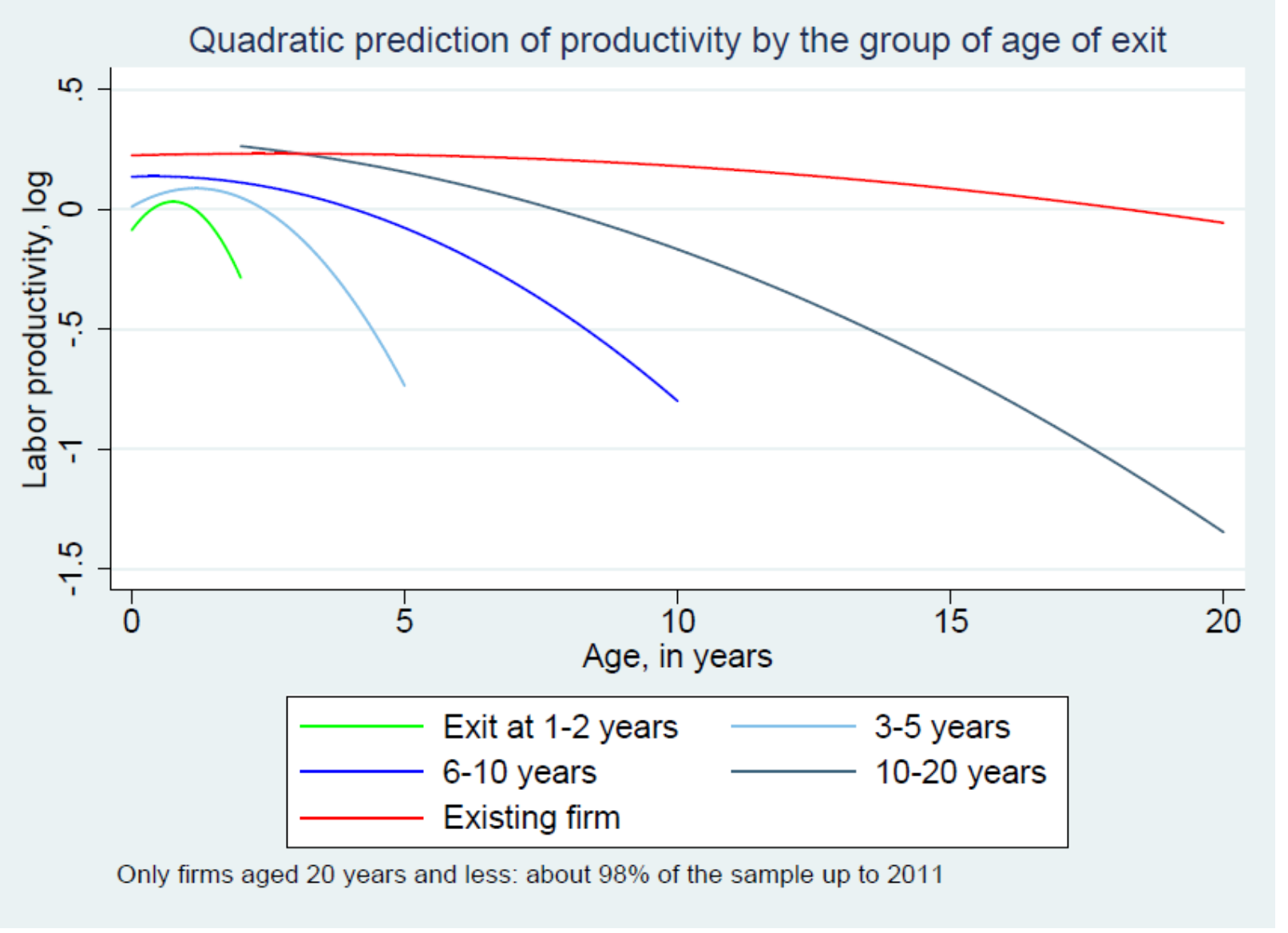

Source: OECD calculations based on OECD-Orbis data.

productivity differs because of the different year when it was recorded for different exit group, or, if some exit groups are over-represented by certain sectors. 


\section{The productivity frontier}

29. Most countries observe a widening gap between firms at the productivity frontier and firms lagging behind the frontier. This gap is often ascribed to fewer knowledge and technology spillovers from productive to less productive firms and slowing innovation among the lagging firms (Andrews, Criscuolo, and Gal $\left(2016_{[11]}\right)$, Kierzenkowski et al.

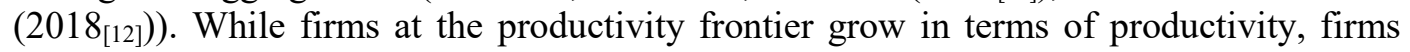
lagging behind the frontier stagnate, and the productivity gap between the frontier and other firms widens. This section assesses to what extent the gap between "the best" and "the rest" is widening in Russia.

\subsection{The gap between frontier and other firms has widened}

30. The gap between the most productive and other firms has widened in Russia (Figure 6.1). Productivity of the top 5\% frontier firms declined until 2007 but from then on increased again, to reach similar levels in 2014 as in 2003 . The productivity of the median and firms at the bottom of the productivity distribution declined almost incessantly. Even for the firm at the bottom quarter distribution of the productivity, the productivity evolution follows the same dynamics as for the bottom $5 \%$ of firms, except for some convergence towards the end of the period.

Figure 6.1. The gap between frontier firms and laggards has widened in Russia

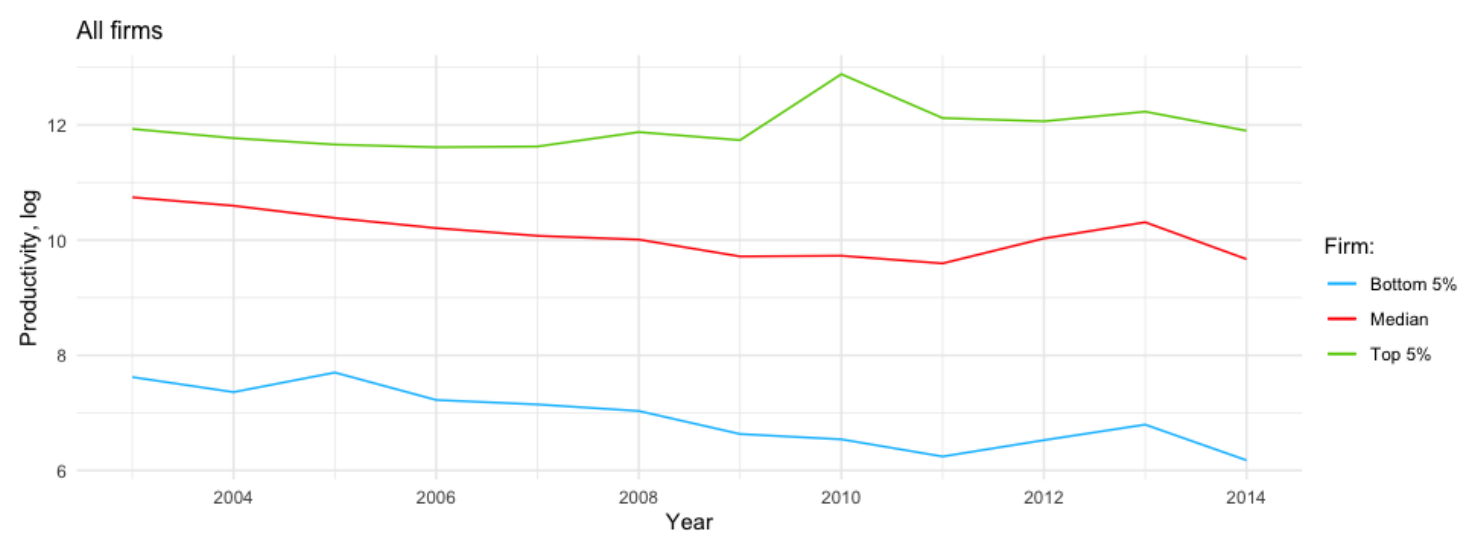

Note: The productivity of the firm at the 5th, 50th and 95 th productivity distribution in given year. Source: $O E C D$ calculations based on $O E C D$-Orbis data. 
Figure 6.2. Productivity frontier firms and laggards, 2003-2014.

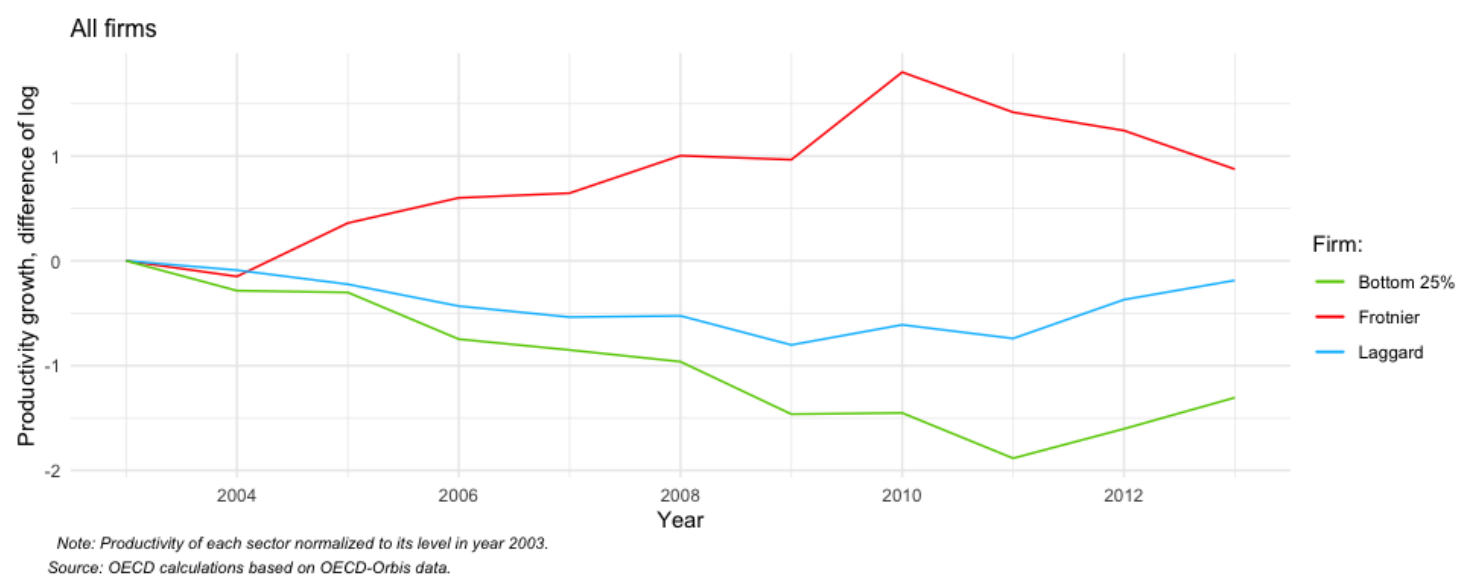

\subsection{Frontier firms and laggards across countries}

31. Russia suffers from the largest gap between the most and the least productive firms of all countries under scrutiny, with the most productive $5 \%$ of all firms more than 60 times more productive than the $5 \%$ least productive (Figure 6.2). ${ }^{9}$ In addition, the most productive firms in Russia lag behind their counterparts in other countries. Not only do the best Russian firms lag behind, productivity of firms at the bottom of the distribution is also considerably lower in Russia than in other major economies. (Figure 6.3). A further disaggregation reveals that the best performing Russian firms in sectors such as transportation and storage or some services are competitive internationally, while the worst performers lag behind considerably (Figure 8.7 in the Annex).

\footnotetext{
${ }^{9}$ Across countries, firms are differently represented in OECD-Orbis compared to national statistics. While it is not expected to influence the results based on frontier firms, as they are well-represented, capturing larger productivity distribution in Russia might display the performance of firms at the bottom of the distribution worse off than in other countries, as the firms at the very bottom in other countries are not captured. More discussion on the representation is in Appendix.
} 
Figure 6.3. Productivity cut-offs by country.

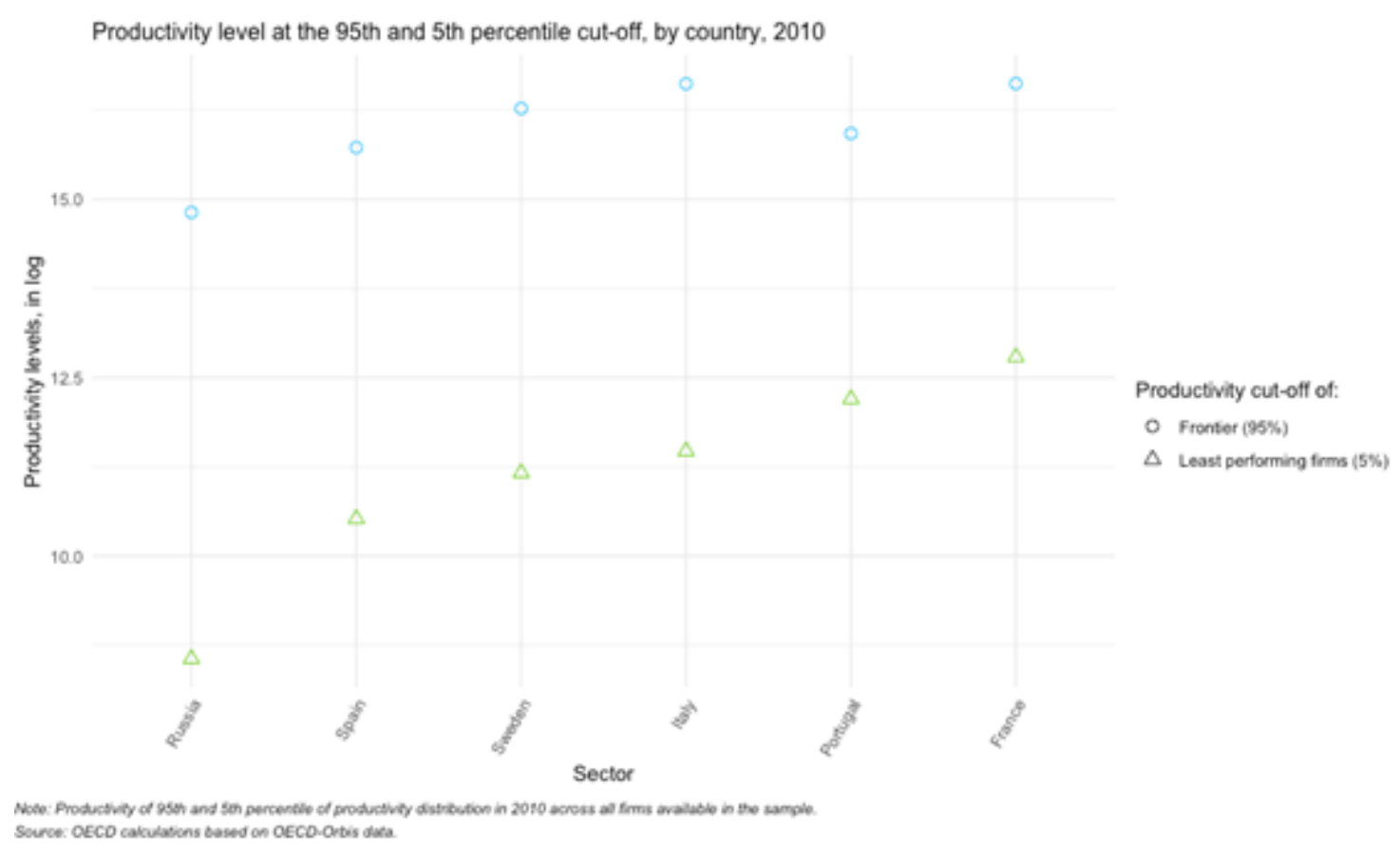

\subsection{Frontier firms by age and size}

32. Frontier firms in Russia were large and old in 2003, which gradually changed by 2014. Due to the entry of very productive new firms, the frontier now consists of smaller and younger firms. The average age has fallen under the average age of laggard firms, although the bottom $25 \%$ of the productivity distribution still consists of comparatively young and small firms. While the laggards grow older, both the top and the bottom firms show a less clear trajectory, probably because of a higher probability of entry and exit of this type of firms (Figure 6.4).

33. Moreover, these firms seem to fail to catch up with the frontier, suggesting an increasing lack of diffusion of knowledge and technology among firms. All three types of firms become smaller over time, but especially the frontier firms (Figure 6.4). 
Figure 6.4. Age and size characteristics of frontier firms and laggards, 2003-2013
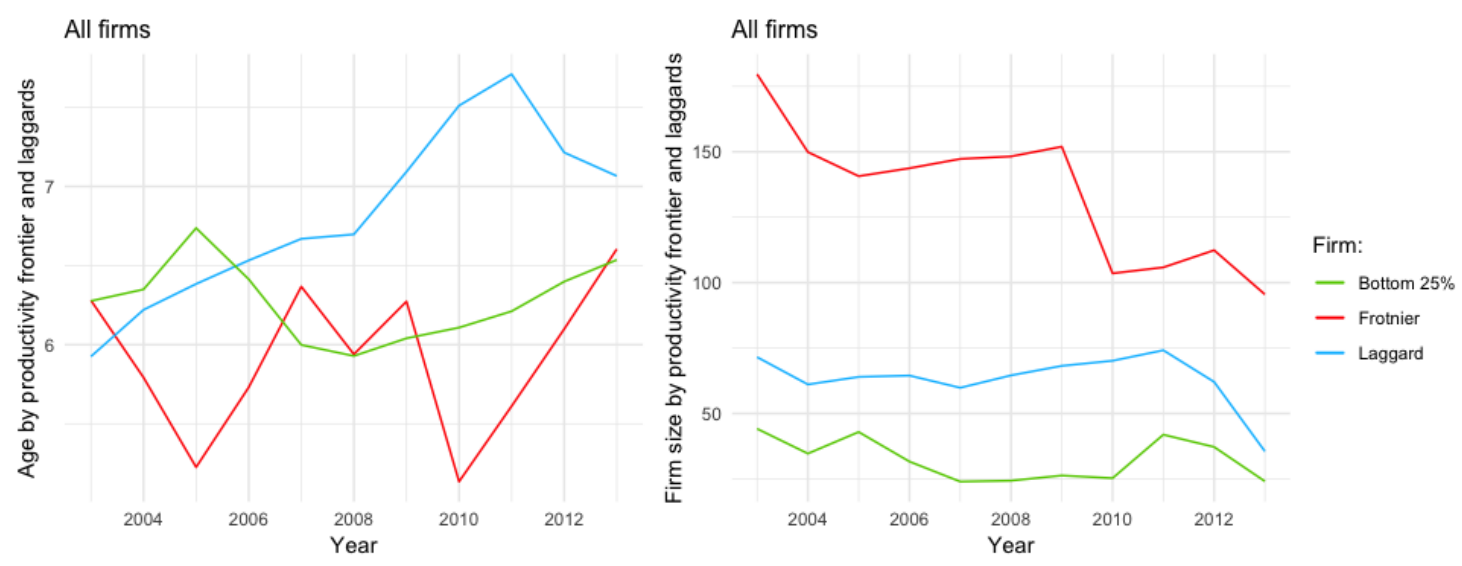

Note: Source: $O E C D$ calculations based on OECD-Orbis data. 


\section{Foreign ownership}

34. The number of foreign firms in Russia increased over time, although their share has declined (Figure 7.1). Today around 8000 foreign firms are active, or about $1.6 \%$ of all firms in Russia. Foreign firms make up around $4 \%$ of all frontier firms. The share of foreign firms among laggard and bottom firms is lower, with around $0.8 \%$ and $0.5 \%$ respectively. Against this background, foreign ownership can be a suitable predictor of a firm's productivity. Domestic firms can benefit from exposure to foreign firms and gain technological knowledge, especially if they are in a supplier relationship with the foreignowned firm (Javorcik and Spatareanu $\left(2008_{[13]}\right)$ and Javorcik $\left(2004_{[14]}\right)$ ). Domestic firms can also benefit if the foreign firm is technologically close to the domestic incumbent and subsequently encourages innovation there to compete on the local market (Fons-Rosen et al., 2017 $[15])$.

Figure 7.1. Foreign firms by frontier, 2007-2013.

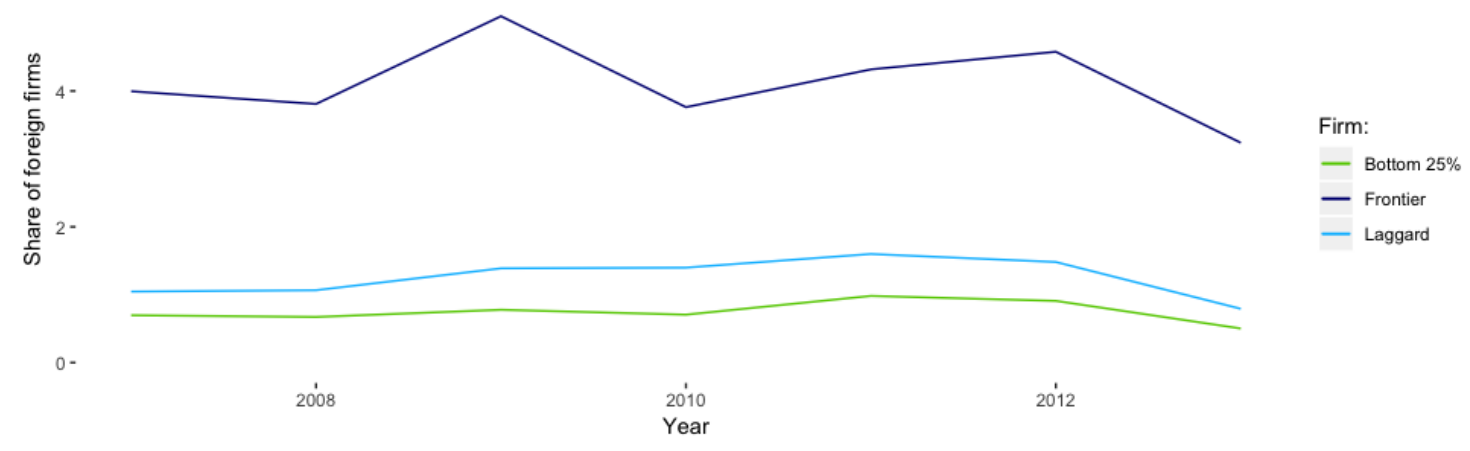

Source: $O E C D$ calculations based on $O E C D$-Orbis data.

35. To understand the productivity differences in firms that are foreign-owned in Russia compared to domestic firms, the following equation is estimated:

$$
\mathrm{lp}_{\mathrm{i}, \mathrm{t}}=\beta_{0}+\beta_{1} \text { foreign owner }{ }_{\mathrm{it}}+\alpha_{\mathrm{t}}+\gamma_{\mathrm{i}}+\varepsilon_{\mathrm{it}}
$$

36. where $i$ subscript refers to firm, and $t$ is year. The dependent variable is labour productivity in $\log$ value. $\beta_{1}$ is then an average impact of foreign ownership on productivity. Fixed effects $\alpha_{\mathrm{t}}$ and $\gamma_{\mathrm{i}}$ control for the time and firm (or sector) dimension. First, the equation is estimated including firm-level control variables such as age, size, and its location, and sector fixed effects, excluding the firm fixed effect. In this case, the outcome shows how much higher the productivity of a foreign-owned firm is compared to a similar domestic firm of a same age, size, in the same sector, and within the same year. Second, estimating the above equation with firm fixed effects shows the increase of productivity within the firm, after a change in ownership from domestic to foreign. ${ }^{10}$

${ }^{10}$ As foreign ownership is defined as ownership by an entity registered in a different country that owns at least $50.01 \%$ of the firm. This includes a change from less than $50 \%$ owned by a foreign firm to majority foreign ownership. 
Moreover, the regression analysis also estimates the impact from changes in foreign ownership in the regional proximity of foreign firms in 82 regions and Nace2 Rev. 2 Level 2 (Division) industry disaggregation and in other sectors on the productivity of the incumbent domestic firms.

Table 7.1. Ownership and productivity, econometric estimation.

\begin{tabular}{|c|c|c|c|c|c|}
\hline & (1) & $(2)$ & (3) & (4) & $(5)$ \\
\hline Dependent variable: & \multicolumn{5}{|c|}{ Labor productivity, log } \\
\hline \multirow[t]{2}{*}{ Foreign-owned firm } & $0.506^{\star \star *}$ & $0.0877^{\star * *}$ & $0.0507^{* * *}$ & $0.0731^{* * *}$ & \\
\hline & $(0.0650)$ & $(0.00864)$ & $(0.0185)$ & $(0.00922)$ & \\
\hline \multirow[t]{2}{*}{ Foreign-owned by a firm from tax haven } & 0.0402 & & $0.0415^{* *}$ & & \\
\hline & $(0.0614)$ & & $(0.0202)$ & & \\
\hline \multirow{2}{*}{$\begin{array}{l}\text { Foreign-owned by a firm from European } \\
\text { country }\end{array}$} & $0.179^{\star \star *}$ & & $0.0596^{* *}$ & & \\
\hline & $(0.0431)$ & & $(0.0245)$ & & \\
\hline \multirow[t]{2}{*}{ State-owned firm } & & & & 0.309 & \\
\hline & & & & $(0.294)$ & \\
\hline \multirow[t]{2}{*}{$\mathrm{Nb}$ of foreign in sector-region, log } & & & & & $0.0092^{* * *}$ \\
\hline & & & & & $(0.00258)$ \\
\hline \multirow[t]{2}{*}{$\mathrm{Nb}$ of firms in sector-region, log } & & & & & $-0.0394^{* * *}$ \\
\hline & & & & & $(0.00414)$ \\
\hline \multirow[t]{2}{*}{$\mathrm{Nb}$ of foreign in region, log } & & & & & $-0.0267^{* * *}$ \\
\hline & & & & & $(0.00408)$ \\
\hline \multirow[t]{2}{*}{$\mathrm{Nb}$ of firms in region, log } & & & & & $-0.110^{* * *}$ \\
\hline & & & & & $(0.00874)$ \\
\hline \multirow[t]{2}{*}{ No foreign in sector-region } & & & & & -0.0037 \\
\hline & & & & & $(0.00330)$ \\
\hline \multirow[t]{2}{*}{ No foreign in region } & & & & & $-0.0225^{\star *}$ \\
\hline & & & & & $(0.0111)$ \\
\hline \multirow[t]{2}{*}{ Age } & $-0.0266^{\star * *}$ & & & & \\
\hline & $(0.00749)$ & & & & \\
\hline \multirow[t]{2}{*}{ Age, squared } & $0.0002^{* * *}$ & & & & \\
\hline & $(4.29 \mathrm{e}-05)$ & & & & \\
\hline \multirow[t]{2}{*}{ Employment, log } & $0.0958^{* * *}$ & & & & \\
\hline & $(0.0229)$ & & & & \\
\hline Observations & 4479207 & 4419144 & 4419144 & 3931230 & 4328571 \\
\hline R-squared & 0.120 & 0.833 & 0.833 & 0.851 & 0.833 \\
\hline Sample & \multicolumn{4}{|c|}{$\begin{array}{l}\text { 2007-2014, } \\
\text { all firms }\end{array}$} & $\begin{array}{c}\text { 2007-2014, } \\
\text { domestic firms } \\
\text { only }\end{array}$ \\
\hline Region controls & Yes & No & No & No & No \\
\hline Sector FE & Yes & No & No & No & No \\
\hline Year FE & Yes & Yes & Yes & Yes & Yes \\
\hline Firm FE & No & Yes & Yes & Yes & Yes \\
\hline
\end{tabular}

Note: Robust standard errors in parentheses.

$* * * \mathrm{p}<0.01, * * \mathrm{p}<0.05, * \mathrm{p}<0.1$

The results report an average effect of the variable on the firm's productivity level. 
Source: OECD-Orbis database.

37. Results in (Table 7.1) can be summarised as follows:

- Controlling for size, age and sectoral composition, foreign firms are on average $50 \%$ more productive, reflecting that foreign ownership is associated with better performance within a sector, even between firms of the same size and age (Column 1). If the firm is owned by an entity based in a European country, productivity rises by another $18 \%{ }^{11}$ Ownership by entities from a country known as a tax haven does not have an additional impact on productivity.

- When a Russian firm is bought by a foreign entity, its productivity rises by about $9 \%$ compared to its previous performance (Column 2 ). If the firm is bought by an entity from a European country, productivity rises by another $2 \%$ (Column 3 ).

- $\quad$ Privatising a state-owned enterprise (SOEs) does not make the firm more productive, suggesting that SOEs are already competitive. Some Russian SOEs belong to highly productive industrial sectors such as mining or transportation. Alternatively, the change in ownership might not imply a real transfer of control and change in practice. However, research for a different observation period suggests that privatisation may foster firmlevel productivity (Brown, Earle and Telegdy, 2006 $[16]$ ).

- An increase of foreign firms in a region is associated with a rise in productivity of domestic firms, albeit not excessively (Column 5). If the number of foreign firms doubles in a region and sector, while the number of domestic firms remains constant, the productivity of a domestic firm increases by $1 \%$, although it may reduce productivity in other sectors. This suggests that foreign competition and knowledge transfer generate a small positive spillover on domestic incumbents in the same sector. Fewer firms in a region are associated with lower productivity, again highlighting the productivity-enhancing effect of stronger competition between firms.

38. Overall results suggest a productivity-enhancing effect of foreign ownership, not only for the foreign-owned firm, but also for other firms in the geographical proximity within the same sector of activity as the domestic firms. However, results also suggest that foreign companies in other sectors within the same region are associated with negative productivity shifts, suggesting insufficient knowledge transfer and competition for human capital between sectors, similar to the negative impact from larger domestic competition in the same region.

11 "Foreign owned" is defined as any foreign ownership of at least $50.01 \%$ share in the firm, as given by the data. Missing information is considered as domestic ownership. The list of countries classified here as tax haven is as follows: Cyprus, Virgin Islands, Netherlands, Luxembourg, Ireland, Seychelles, Panama, and Gibraltar. The list of European owners is: Austria, Belgium, Czech Republic, Denmark, Estonia, Finland, France, Germany, Hungary, Poland, Portugal, Spain, Sweden, United Kingdom.

Note by Turkey

The information in the documents with reference to "Cyprus" relates to the southern part of the Island. There is no single authority representing both Turkish and Greek Cypriot people on the Island. Turkey recognizes the Turkish Republic of Northern Cyprus (TRNC). Until a lasting and equitable solution is found within the context of the United Nations, Turkey shall preserve its position concerning the "Cyprus issue".

Note by all the European Union Member States of the OECD and the European Union

The Republic of Cyprus is recognised by all members of the United Nations with the exception of Turkey. The information in the documents relates to the area under the effective control of the Government of the Republic of Cyprus. 


\section{What makes a productive Russian firm? A multivariate regression}

To conclude, a multivariate regression brings together all determinants analysed so far potentially affecting the productivity of a firm in Russia. A log-linearized equation with year- and sector-fixed effects helps asses the role of size, age, industrial sector and location for the productivity of an individual firm. Results in Table 8.1 can be summarised as follows:

- Larger firms are more productive (column 1). A firm with $10 \%$ more employees has $1 \%$ higher productivity.

- However, the impact is not homogenous along the size dimension (column 2). While very small firms between 10 and 19 employees are even less productive than micro firms and small firms with 20 to 49 employees are not significantly different from micro firms. Medium-sized firms are the most productive. Actually, an average medium-sized firm is approximately $64 \%$ more productive than a micro firm. Large firms with 250 and more employees are about $29 \%$ more productive than a micro firm.

- Age has a negative impact on productivity, implying that productivity tends to decline when firms grow older (column 3). This corroborates findings on the productivity decline of firms that exit the market (Figure 5.6).

- Productivity is strongly determined by location (Column (4)). The North-West federal region is the most productive region with $11 \%$ higher productivity, probably owing to the strong presence of mining firms. The least productive region, with $21 \%$ lower productivity than the central federal region, is the North Caucasian District, which is also very sparsely populated. The regional premia of each of the seven federal regions is compared to the central federal region, which hosts about $37 \%$ of all Russian firms.

- Even controlling for varying industrial composition, productivity differs significantly across the seven federal regions (Column 5). It appears that productivity is much bound by regional idiosyncrasies, suggesting insufficient inter-regional capital and labour mobility (Blöchliger and Durand-Lasserve, $2018_{[17]) \text {. }}$

Overall, the findings of the multivariate regression analysis corroborate the findings of the different sections of this paper: The most productive firms are getting smaller and younger, yet medium-sized firms are still the most productive. Older firms become less productive. Productivity differs by sector, and the regional productivity gap remains large even when controlling for the sectoral composition. 
Table 8.1. A productive Russian firm: econometric estimation.

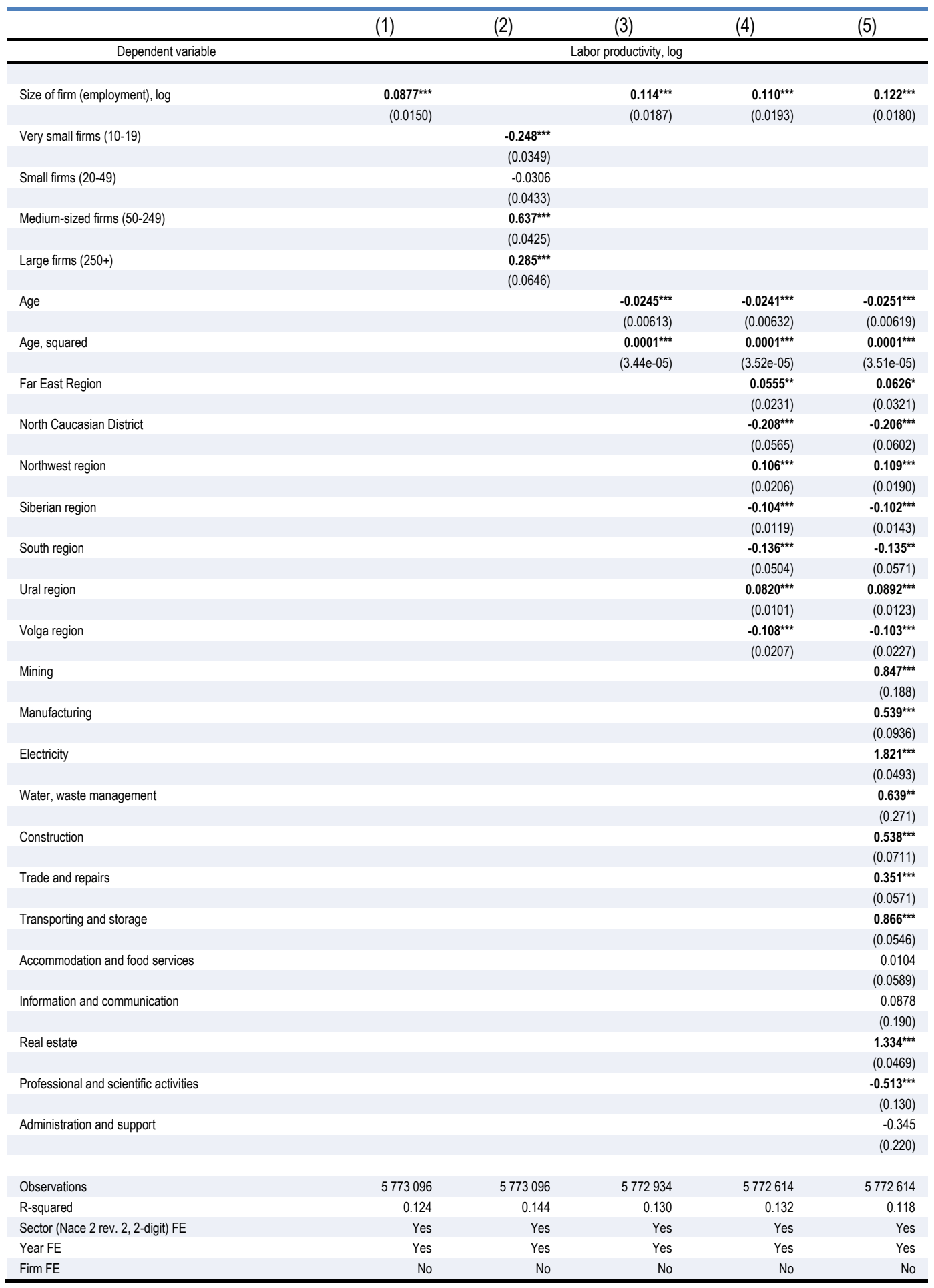

Note: Robust standard errors in parentheses.

$* * * \mathrm{p}<0.01, * * \mathrm{p}<0.05, * \mathrm{p}<0.1$

The results report an average effect of the variable on the firm's productivity level.

Source: OECD-Orbis database. 


\section{Appendix}

39. The appendix section consists of two parts. The data treatment gives a detailed record on how the data used for this analysis has been handled and more information on the representativeness. Then, the section Additional results lists all graphics and tables referred to in the text, with complementary results or robustness check verifications.

\subsection{Data treatment}

40. The data collecting excludes sole entrepreneurs (incl. collective farms) and branches/representative offices as these entities are not obliged to file the records of their financial accounts.

\subsubsection{Financial information}

41. The dataset provides real value of gross output and employment levels, and consists of a total of 5776500 year-firm observations on Russian firms. The Russian firm data does not include information on value added or wage bill, while such variables are available for other countries. However, the labour force and gross output information is available for most of the observations. Financial records are match with non-financial information using the firm identifier $B V D_{-} I D$, which is a unique identification code constructed by BvD that is for the most part constructed as first two letters being the country identifier and the next 10 (or more) digits identify the firm within given country. It is possible to distinguish between consolidated and unconsolidated accounts; if both pieces of information are available for a firm, preference is given to unconsolidated information. The individual datasets on financial attributes, location and ownership are matched using the first 12 signs of the BvD id number.

\subsubsection{Additional data}

42. BvD supplies also information on the postal code and regions. About 3000 firmyear observations are not included in the contact information dataset. The remaining sample has 5773230 observations containing both financial and contact information. Finally, the financial-address dataset is merged with information on shareholders, available for years 2007-2014. The raw data include the subsidiary firm's id as well as the shareholder firm's ID. 4051067 firm-year observations were matched. The matched sample displays $23.3 \%$ firms have some foreign shareholder, and $12 \%$ of observations have a majority owner foreign, while $48 \%$ has a majority domestic ownership (DUO 50c). However, the results must be interpreted with caution. Here, the foreign ownership is identified such that if the shareholder's id starts by anything other than "RU", including codes such as "WW", which signifies that the information is gathered from websites and individual ownership. "WW" constitutes the highest share of majority foreign ownership, about $80 \%$ of observations. Among the identified foreign countries, $5.8 \%$ of foreign majority companies are Cyprus*, $1.86 \%$ Virgin Islands, Germany with $1.13 \%$, Unknown $1.5 \%$, and Great Britain 0.82\%.

* Note by Turkey

The information in the documents with reference to "Cyprus" relates to the southern part of the Island. There is no single authority representing both Turkish and Greek Cypriot people on the Island. Turkey recognizes the Turkish Republic of Northern Cyprus (TRNC). Until a lasting and equitable solution is found within the context of the United Nations, Turkey shall preserve its position concerning the "Cyprus issue".

Note by all the European Union Member States of the OECD and the European Union

The Republic of Cyprus is recognised by all members of the United Nations with the exception of Turkey. The information in the documents relates to the area under the effective control of the Government of the Republic of Cyprus. 


\subsubsection{Data cleaning}

43. The harmonizing and cleaning procedures include industry-level PPP conversion and deflation, ${ }^{12}$ as well as computing the productivity and capital stock variables. Data cleaning includes removing the firms of the $0.5 \%$ extremes of growth rate distribution of productivity measures, employment, capital, capital ratio, intermediates, value added and gross output at least once during their existence in the sample. This ensures excluding firms that underwent acquisitions or similar shocks that could under-determine the data analyses. The data cleaning also removes financial (Nace 2 Rev.2, Section K) and administrative sectors (Nace 2 Rev.2: 84.00 and above) (Gal (2013 $\left.{ }_{[18]}\right)$ Andrews, Criscuolo, and Gal $\left.\left(2016_{[11]}\right)\right)$.

\subsubsection{Data representativeness}

44. To understanding the coverage of the OECD-Orbis data, the data is compared to partial data obtained from Rosstat. Rosstat reports the total number of firms registered in Russia at the end of the year as obtained from a sample survey. The total number of firms, in Table 11.2, Column 1, includes a large share of individual enterprises. As OECD-Orbis dataset reports on firms that employ at least one employee, this study does not evaluate individual firms. Further, Rosstat statistics include a large number of small firms. The classification of firms by their size is slightly different from the OECD classification, used throughout this study. In Rosstat, the micro firms are those with 15 and less employees, small firms have over 15 to 100 employees, and medium firms are those with above 101 employees, but with less than 250, as defined by legislation introduced in $2007 .{ }^{13}$ The comparison relies on the data from the reports between years 2003 and 2014.

${ }^{12}$ The cleaning procedures are performed within the ECO department, under supervision of Peter Gal. We are thankful for the cooperation and information sharing that makes our work more efficient.

${ }^{13}$ Prior to 2007 re-definition of small firm used by Russian statistical agency today, the 1994 definition included firms with up to 100 employees in industry, construction and transport; 60 employees in agricultural and scientific firms, and up to 30 employees in wholesale trade and consumer services, and finally up 50 in other sectors. 
Table 8.2. Observations on Russian firms.

OECD-Orbis vs. Rosstat

\begin{tabular}{rrrrrr}
\hline Year & \multicolumn{1}{c}{ Total Rosstat } & \multicolumn{1}{c}{ Total O-Orb* } & \multicolumn{1}{c}{ Small Rosstat } & \multicolumn{1}{c}{ Small O-Orb* } & \multicolumn{1}{c}{ Small, share O-Orb*/Rosstat } \\
\hline 2003 & 3845300 & 260277 & 890900 & 56524 & 0.063 \\
2004 & 4149800 & 326491 & 953100 & 81651 & 0.086 \\
2005 & 4417100 & 327093 & 979300 & 114612 & 0.117 \\
2006 & 4506600 & 378968 & 1032800 & 150412 & 0.146 \\
2007 & 4674900 & 401651 & 1137400 & 148714 & 0.131 \\
2008 & 4767300 & 436168 & 282700 & 214288 & 0.758 \\
2009 & 4907800 & 428601 & 227800 & 250850 & 1.101 \\
2010 & 4823300 & 424104 & 219700 & 261223 & 1.189 \\
2011 & 4866600 & 424954 & 242700 & 241910 & 0.997 \\
2012 & 4886400 & 520091 & 238100 & 289030 & 1.214 \\
2013 & 4843400 & 967980 & 234500 & 371263 & 1.583 \\
2014 & 4886000 & 871818 & 235600 & 427439 & 1.814 \\
\hline
\end{tabular}

Note: The size of a small firm (15-100 employees) is officially defined in 2007. Most likely, the group of small firms prior to 2007 includes firms with less than 15 employees, which drives the number of firms up. Source: Rosstat and OECD calculations based on OECD-Orbis data.

45. Due to the differences in measurement, the validity of comparison of the small firms' coverage can be reported only starting from 2008, as the previous years' reporting is not employing the same definition of firm size. Table 8.2 reports the share of small firms from OECD-Orbis in the data from Rosstat. In 2008, about 3/4 of the small firms were also reported in OECD-Orbis. In the years after, OECD-Orbis database includes actually more small firms than the government reports; the figure higher by about 10 to $80 \%$ than the actual number in Rosstat. Some discrepancies arise from varying definition of firms size. In Rosstat, not only the number of employees is taken into account; moreover, the classification is also extended to turnover. The micro-firms have a turnover under RUB60 mil, small firms under RUB400mil, and medium firms RUB1 billion. Additional conditions of being classified as small or medium firm is a restriction of firm ownership that does not exceed $25 \%$ by an enterprise that is not small or medium in its size-qualification, respectively. As OECD-Orbis does not capture these data requirements of turnover and ownership in the data precisely, this comparison relies on approximate employment comparison. Therefore, some firms might be classified into the group by employment, where, in fact, they belong to higher category according to Russian statistical institute guidelines, and consequently the OECD-Orbis data contains more firms in bins of small and medium size. Also, note a sharp drop of the number of firms between 2008 and 2009 in the Rosstat reporting. As later, the number of small firms grows only slightly; such a jump is most likely coming from the changes in the definition. The representativeness of OECDOrbis data of Russian small firms appears to be excellent, with close to a perfect coverage.

46. Moreover, an additional check compares shares for micro and medium firms between 2012 and 2014 using the data from Fed Web Portal for small and medium-sized enterprises before this period. Table 8.3 reports the number of firms by size category as reported by Rosstat and number of firms in equivalent employment size definition in OECD-Orbis. The difference between the total number of enterprises in Russia and those captured in the data used in the reporting is mainly coming from micro-firms. The average share of micro firms in the OECD-Orbis sample is about $20 \%$ of total as reported by Rosstaf. It is important to highlight that firms in the OECD-Orbis sample are present for at least two periods, removing all temporary establishments. On the other hand, the OECD-Orbis data 
contain more than a double of medium-sized firms. Again, this can be due to the size definition discrepancy that it is not possible to match due to unavailability of turnover data. Such overrepresentation of firms allows concluding that the OECD-Orbis data represents the economy of those firms with 10 and more employees fairly well. The larger the firms are, the better represented they are in OECD-Orbis.

Table 8.3. Observations on micro and medium-sized Russian firms.

OECD-Orbis vs. Rosstat.

\begin{tabular}{lllllll}
\hline Year & Micro R & Micro O & Share Micro (O/R) & Medium R & Medium O & Share Medium, (O/R) \\
\hline 2012 & 1759973 & 180427 & 0.103 & 13767 & 29845 & 2.168 \\
2013 & 1828589 & 544640 & 0.298 & 13684 & 30765 & 2.248 \\
2014 & 1868201 & 398637 & 0.213 & 13672 & 28010 & 2.049 \\
\hline
\end{tabular}

Note: Medium firm has between 101 and 250 employees. Micro enterprise is defined as the one with 15 and less employees.

Source: Rosstat and OECD calculations based on OECD-Orbis data.

47. The evolution of number of firms by firm size bin is displayed in Figure 8.1. The largest firms, or those with 250 and more employees, are represented by about 15-16,000 firms, with a slight drop in 2014 to 14,000, most likely due to the incomplete dataset for the last year of the OECD-Orbis data sample ${ }^{14}$. The number of medium-sized firms is increasing slightly over time, and similarly, the number of very small and small firms increases. As seen in Table 8.2, the representativeness of small firms compared to whole economy improved from 2008 on, and as displayed in Figure 11.1, this is partly due to an increase of the number of firms in OECD-Orbis data. The second reason is, as already discussed, a change in the definition of small firms. Lastly, the sharp increase of micro firms after 2012 is responsible for an improved coverage of these firms (partially represented by micro enterprises within Russian definition, i.e. less than 15 employees, as displayed in Table 8.2). As it is expected that most of the firms enter the market as small and exit the market if not performing well, the drop in the number of micro firms after 2007 might relate to firm exit after the recession and plays a role in productivity shifts as discussed in more detail in Section 4.

\footnotetext{
${ }^{14}$ Reporting might be delayed for the last year of the dataset.
} 
Figure 8.1. Number of firms by their size, 2003-2014.

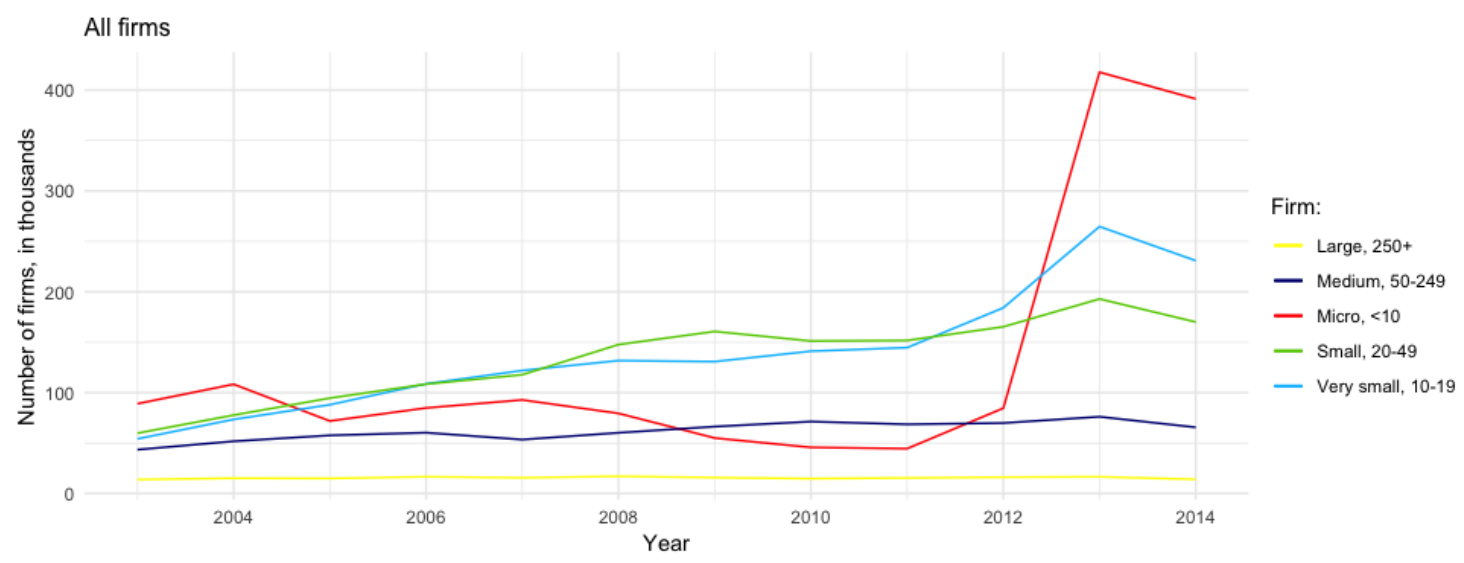

Source: $O E C D$ aggregations based on $O E C D$-Orbis data.

\subsection{Additional results}

48. Complementary graphics in Figure 8.2 displays how the number of firms, employment, and gross output is distributed by type of firm. It provides additional evidence of the Russian economy relying on large firms with employment and gross output concentrated in firms with 250 and more employees. Additionally, a majority of the output is produced by the best $5 \%$ - frontier - firms that employ about $11 \%$ of the workforce. Lastly, graph (C.) displays the redistribution by region, with Central region being most dominant.

Figure 8.2. Redistribution of firms, employment, and gross output by type of firm or its location, average 2003-2013
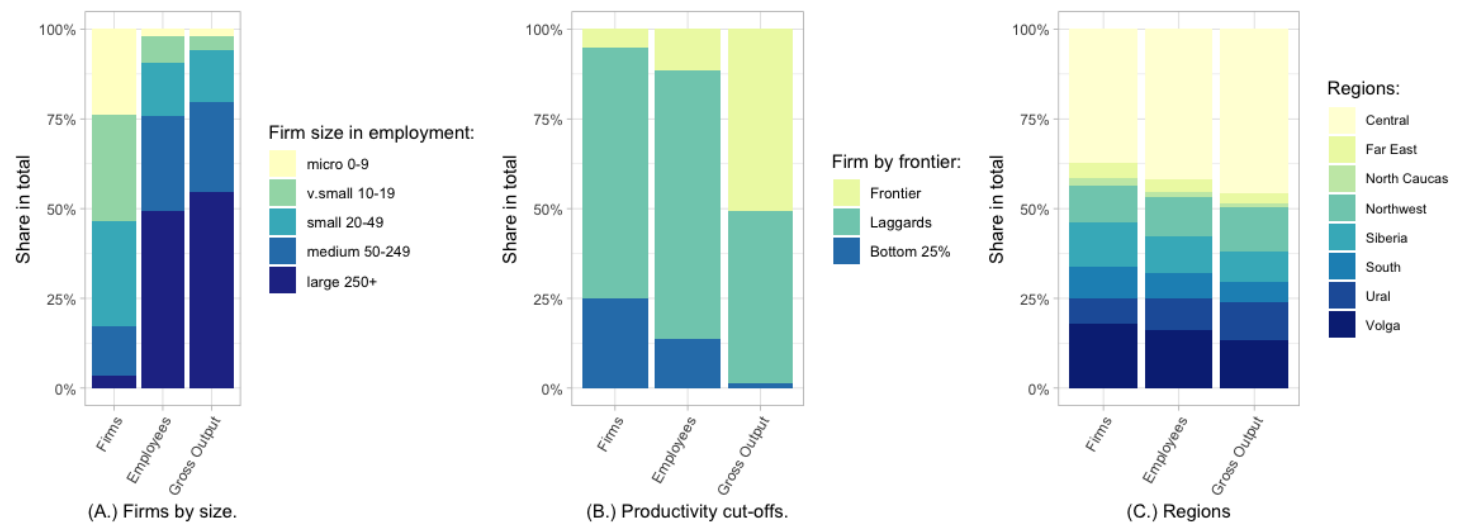

2. In Figure (A), Employment group calcuated from average employment of the firms's presence in the sample
3. In Figure (B.), the firms are assigned to their group every year for every sector based on their total average

Sources: OECD calculations based on OECD-Orbis data)

49. As one of the concerns of productivity evolution might be that the set of firms in Russia from which the average productivity is extracted is not of the same representation of firms as in other countries, the robustness test, as displayed in Figure 8.3, takes the first 100 best firms in each Nace2 sector, while displaying comparable outcomes to Figure 2.4 
Figure 8.3. Productivity evolution in selected countries.

Average across 100 best firms in each Nace 2 2-digit sector, 2003-2014.

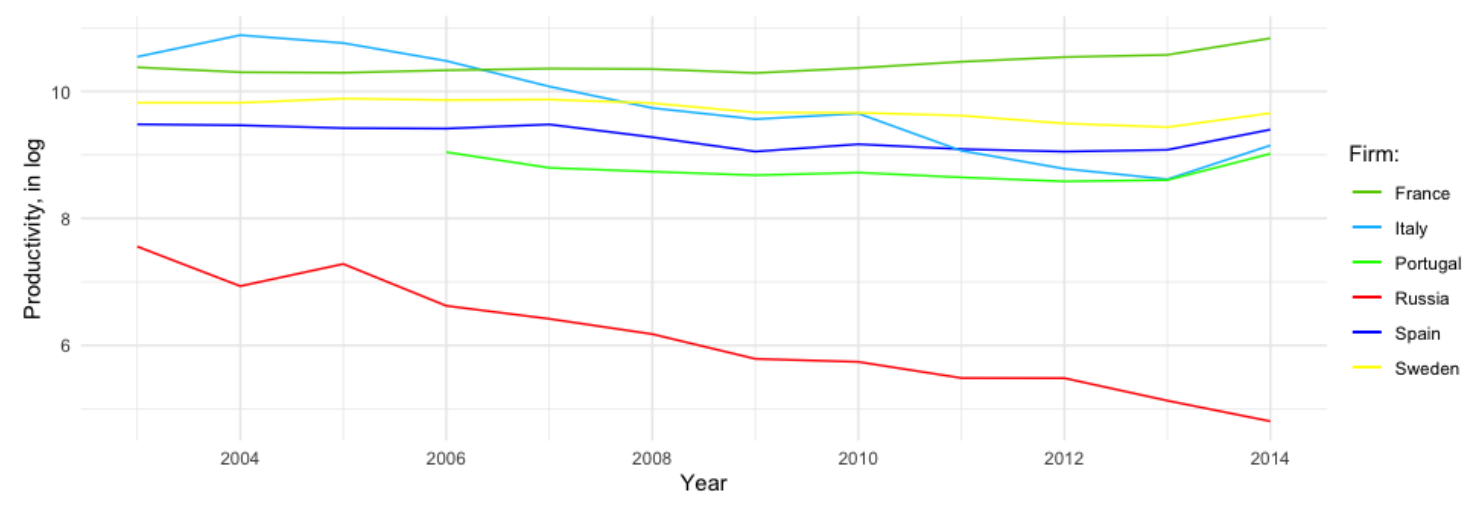

Note: Log value of average firm's productivity.

Source: $O E C D$ calculations based on $O E C D$-Orbis data.

50. To provide a robustness check especially considering the representativeness of the data for small firms as described in Appendix 8.1.4, the additional graphics provide supplementary figures that portray firms with an average employment of 20 and more employees. Figure 8.4 provides complementary information to Figure 3.1, with the summary restricted to large firms.

Figure 8.4. Productivity evolution of firms by sector.

Firms with 20 and more employees, 2003-2014.

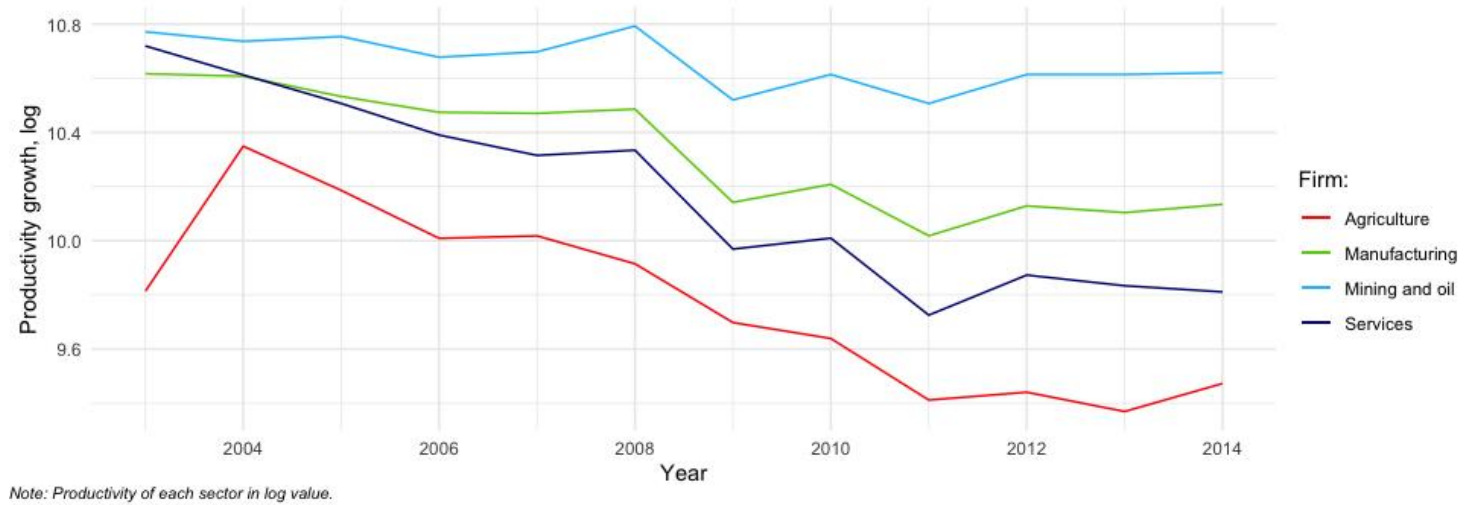

Note: Productivity of each sector in log value.
Source: $O E C D$ calculations based on OECD-Orbis data.

51. Figure 8.5 restricts the analysis of productivity by employment growth to large manufacturing firms, and while the productivity curves are smoothed-out, the evidence is similar to that of Figure 4.2. 
Figure 8.5. Productivity by employment growth.

Large manufacturing firms, 2003-2014.

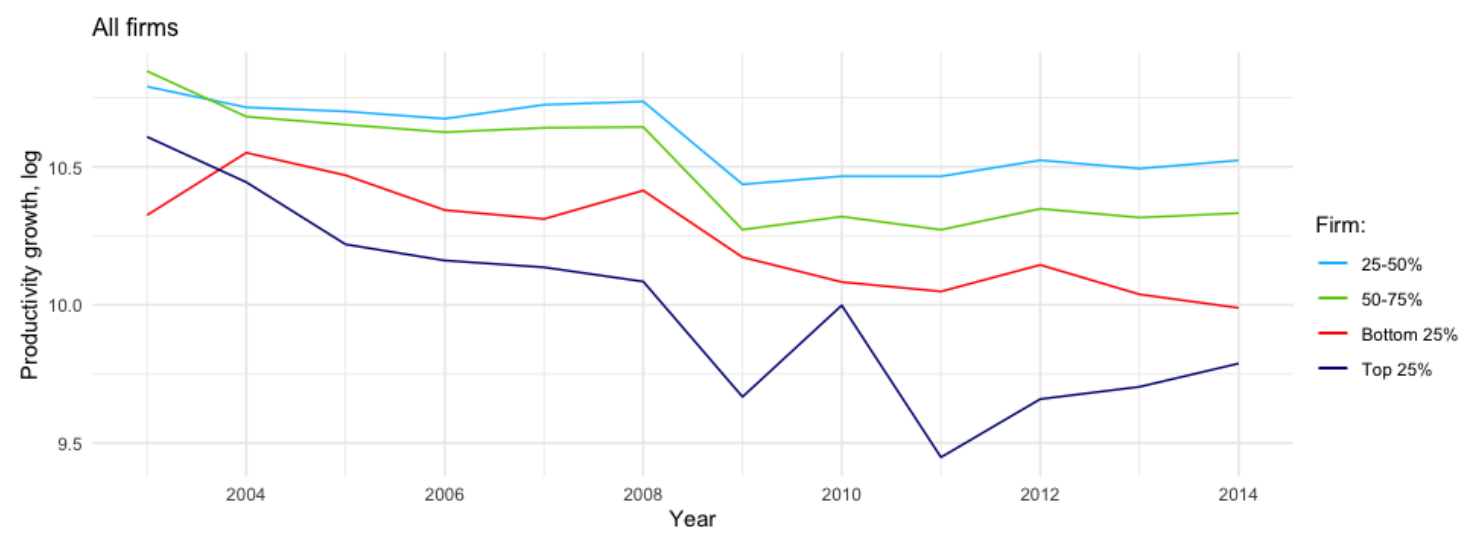

Note: Productivity of each sector normalized to its level in year 2003.

Source: $O E C D$ calculations based on $O E C D$-Orbis data.

52. Figure 8.6 refers to analysis in Section 5. and displays the number of firms in each age group. Note that only Young and Stable firms represent firms of similar number of ages ( 4 and 5 respectively), while New firms stands for only those firms aged 0 or 1 , and Old firms can range anywhere from 10 years up. Note that the number of firms after age 20 sharply decreases. The surge of new firms in 2013, as this increase happens in all age groups, is due to accounting and reporting issues.

Figure 8.6. Firm count by age group.

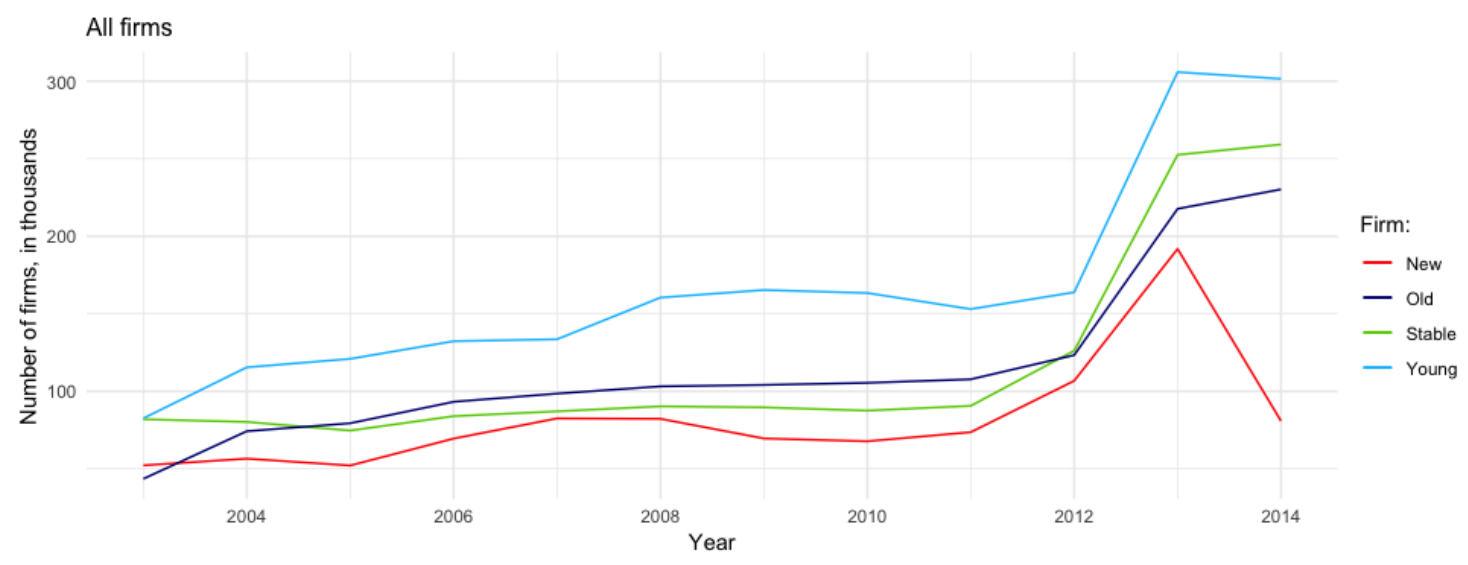

53. In the Figure 8.7, the additional disaggregation by a Section of the industrial sectors (Level 1) provides more insights into which areas Russian frontier and bottom-productivity firms perform relatively close to their counterparts in other countries while there are some sectors where the performance lags behind considerably. This Figure complements Figure 6.3 . 
Figure 8.7. Productivity cut-offs for frontier and laggard firms.

Country-sector disaggregation.

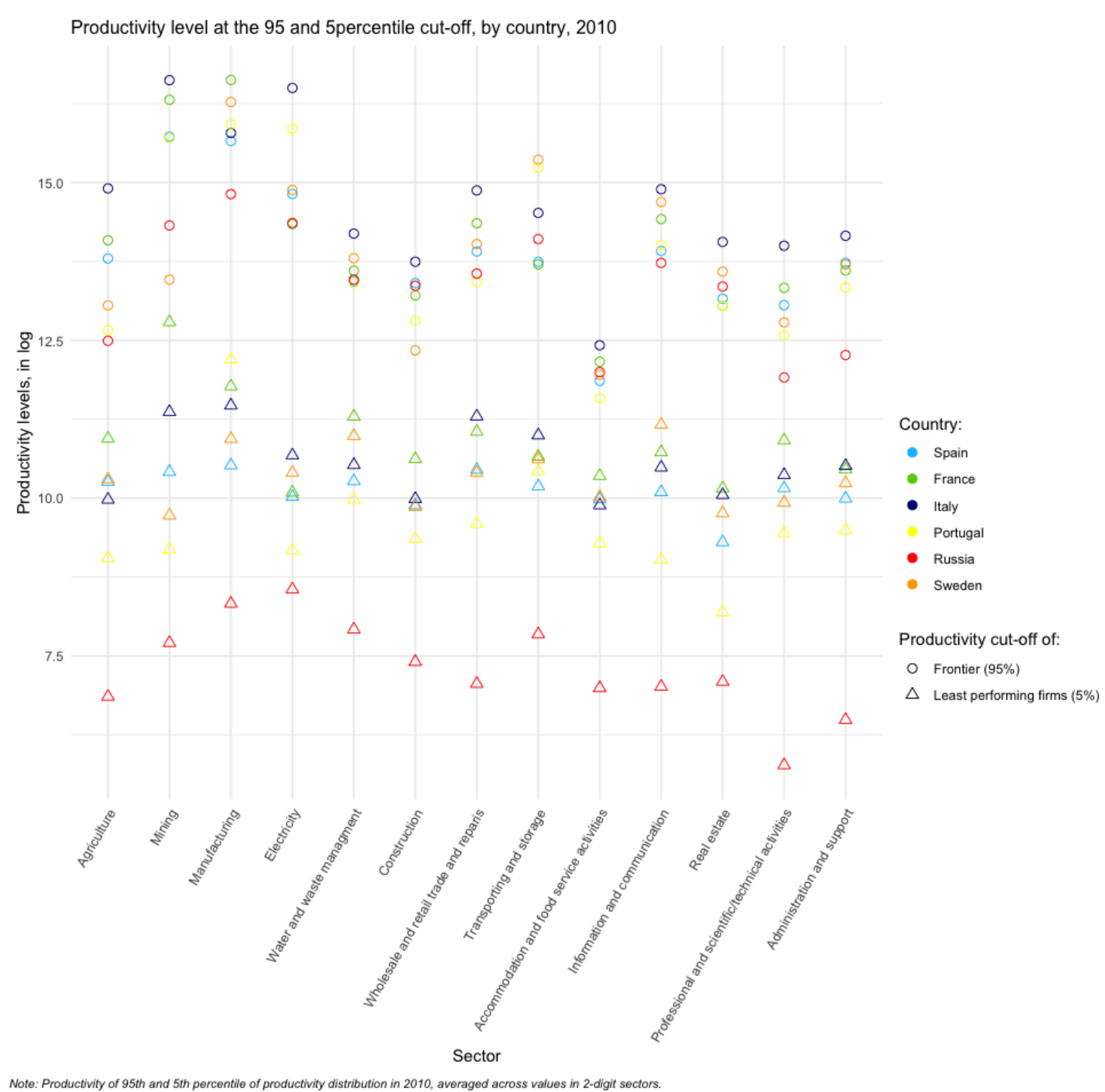
Source: OECD calculations based on OECD-Orbis data. 


\section{References}

Andrews, D. and F. Cingano (2014), "Public policy and resource allocation: evidence from firms in OECD countries", Economic Policy, Vol. 79, pp. 253-296.

Andrews, D., C. Criscuolo and P. Gal (2016), "The Global Productivity Slowdown, Technology Divergence and Public Policy: A Firm Level Perspective", forthcoming, OECD Publishing, Paris.

Bajgar, M. et al. (2019), "Industry Concentration in Europe and North America", OECD Productivity Working Papers, No. 18, OECD Publishing, Paris, https://dx.doi.org/10.1787/2ff98246-en.

Bernard, A. and J. Jensen (1999), Exceptional exporter performance: cause, effect, or both?, http://mba.tuck.dartmouth.edu/pages/faculty/andrew.bernard/jie-eep.pdf (accessed on 19 June 2019).

Bernard, A., A. Moxnes and Y. Saito (2015), Production networks, geography and firm performance, National Bureau of Economic Research.

Blöchliger, H. and O. Durand-Lasserve (2018), "The drivers of regional growth in Russia: A baseline model with applications", OECD Economics Department Working Papers, No. 1523, OECD Publishing, Paris, https://dx.doi.org/10.1787/9279f6c3-en.

Brown, D., J. Earle and A. Telegdy (2006), "The Productivity Effects of Privatization: Longitudinal Estimates from Hungary, Romania, Russia, and Ukraine", Journal of Political Economy, Vol. 114, pp. 61-99.

Criscuolo, C., P. Gal and C. Menon (2014), "The Dynamics of Employment Growth: New Evidence from 18 Countries", OECD Science, Technology and Industry Policy Papers, No. 14, OECD Publishing, Paris, https://dx.doi.org/10.1787/5jz417hj6hg6-en.

EIB (2013), Small and Medium Entrepreneurship in Russia, https://www.eib.org/attachments/efs/econ study small and medium entrepreneurship in ru ssia en.pdf (accessed on 19 June 2019).

Fons-Rosen, C. et al. (2017), Foreign Investment and Domestic Productivity: Identifying Knowledge Spillovers and Competition Effects, https://www.congress.gov/bill/115thcongress/senate-bill/2098.

Gal, P. (2013), "Measuring Total Factor Productivity at the Firm Level using OECD-ORBIS", OECD Economics Department Working Papers, No. 1049, OECD Publishing, Paris, https://dx.doi.org/10.1787/5k46dsb251s6-en.

Haltiwanger, J. et al. (2017), High Growth Young Firms: Contribution to Job, Output and Productivity Growth, https://www.census.gov/content/dam/Census/library/workingpapers/2017/adrm/carra-wp-2017-03.pdf (accessed on 18 July 2019).

Haltiwanger, J., R. Jarmin and J. Miranda (2011), "Who Creates Jobs? Small vs. Large vs. Young*”, No. Working Paper 16300, NBER, http://econweb.umd.edu/ haltiwan/size age paper_R\&R_Aug_16_2011.pdf (accessed on 11 October 2019). 
Javorcik, B. and M. Spatareanu (2008), "To share or not to share: Does local participation matter for spillovers from foreign direct investment?", Journal of Development Economics, http://dx.doi.org/10.1016/j.jdeveco.2006.08.005.

Kierzenkowski, R. et al. (2018), SECTORAL AND REGIONAL DISTRIBUTION OF EXPORT SHOCKS: WHAT DO TWO HUNDRED THOUSAND UK FIRM OBSERVATIONS SAY?, http://www.oecd.org/eco/workingpapers. (accessed on 20 June 2019).

OECD (2019), OECD SME and Entrepreneurship Outlook 2019, OECD Publishing, Paris, https://dx.doi.org/10.1787/34907e9c-en.

OECD (2017), Economic policy Reforms: Going for Growth, OECD Publishing, http://dx.doi.org/10.1787/growth-2017-en.

OECD (2016), Entrepreneurship at a Glance 2016, OECD Publishing, Paris, https://dx.doi.org/10.1787/entrepreneur aag-2016-en.

OECD (2014), OECD Economic Surveys: Russian Federation 2013, OECD Publishing, Paris, https://dx.doi.org/10.1787/eco_surveys-rus-2013-en.

Smarzynska Javorcik, B. (2004), "Does foreign direct investment increase the productivity of domestic firms? In search of spillovers through backward linkages", The American Economic Review, Vol. 94/3, pp. 605-627. 